\title{
MEKANISME PENGENDALIAN MONETER DENGAN INFLASI SEBAGAI SASARAN TUNGGAL
}

\author{
Erwin Haryono \\ Wahyu Agung Nugroho \\ Wahyu Pratomo *)
}

Sementara diskusi teoritis tentang mekanisme transmisi kebijakan moneter belum konklusif, studi ini menyarankan perumusan kebijakan moneter untuk mencapai sasaan tunggal inflasi berdasarkan transmisi suku bunga. D alam hal ini, suku bunga jangka pendek berfungsi sebagai target operasional kebijakan moneter yang diharapkan dapat mempengaruhi agregat demand, untuk selanjutnya mempengaruhi pencapaian sasaran inflasi. Selain itu, perubahan suku bunga juga dapat melewati jalur nilai tukar dan ekspektasi masyarakat sebelum akhirnya mempengaruhi inflasi. Tidak seperti kerangka kebijakan moneter melalui jalur agregat moneter, kerangka ini tidak secara eksplisit memasukan fungsi intermediate target. Sebagai penggantinya, beragam information variables berfungsi sebagai indikator tekanan inflasi.

Sebagai acuan bagi kebijakan moneter, yaitu bagaimana suku bunga jangka pendek harus disesuaikan untuk mencapai sasaran inflasi, disarankan penggunaan monetary policy rules yang dikembangkan dari Taylor rule dengan melakukan beberapa penyesuaian. U ntuk hal ini, diperlukan penelitian tersendiri dengan mengakomodasi karakteristik yang relevan untuk kasus Indonesia. Namun, dengan terdapatnya unsur ketidakpastian dalam mekanismetransmisi, penggunaan policy rule tersebut tidak dimaksudkan untuk digunakan secara kaku (strict). Dalam hal ini, masih tersedia ruang bagi kebijakan yang bersifat discretionary, yaitu dengan melakukan assesment atas informasi yang diperoleh dari berbagai information variables.

\footnotetext{
*) Tim penyusun adalah Asisten Peneliti Ekonomi di Bagian Analisis dan Perencanaan Kebijakan (APK), Direktorat Riset Ekonomi dan Kebijakan Moneter (DKM) Bank Indonesia. Tim penyusun menyampaikan penghargaan yang tinggi kepada Iskandar dan Doddy Zulverdi dari Bagian APK atas masukan yang diberikan sejak perencanaan penelitian. Demikian halnya, ucapan terimakasih juga disampaikan kepada peserta workshop di Bagian APK dan DKM atas segala masukan yang diberikan.
} 


\section{Pendahuluan}

ejalan dengan kecenderungan banyak bank sentral di dunia untuk memfokuskan sasaran kebijakan moneter kepada pencapaian stabilitas harga, pasal 7 dalam UU

Nomor 23 Tahun 1999 tentang Bank Indonesia secara eksplisit mengamanat-kan tujuan "mencapai dan memelihara kestabilan nilai rupiah" sebagai sasaran kebijakan moneter. Terminologi "kestabilan nilai rupiah" tentu saja dapat menghasil-kan interpretasi yang berbeda: kestabilan secara internal - yaitu kestabilan harga (stable in terms of prices of goods and services), atau kestabilan secara eksternal - yaitu kestabilan nilai tukar (stable in terms of prices of other currencies). Pilihan atas interpretasi yang berbeda tersebut mempunyai implementasi yang sangat berbeda dalam hal kebijakan moneter yang harus dilakukan untuk mencapai sasaran kestabilan rupiah yang dipilih.

Paper ini mengartikan kestabilan rupiah dalam interpretasi yang pertama, yaitu kestabilan harga yang diukur dengan tingkat inflasi, baik karena alasan teoritis bahwa kestabilan harga merupakan sasaran yang paling relevan bagi kebijakan moneter, maupun karena pasal-pasal maupun penjelasan pasal-pasal lain dalam UU Bank Indonesia lebih sesuai dengan interpretasi tersebut. Argumen lain adalah bahwa dalam jangka panjang, pencapaian kestabilan harga dapat mengarahkan kestabilan nilai tukar.

Rationale utama dari penerapan single objective kestabilan harga didasarkan pada relevansi sasaran terebut sebagai tujuan kebijakan moneter. Dalamjangka panjang, kebijakan yang dapat dilakukan oleh suatu bank sentral - melalui sisi permintaan - hanya dapat mempengaruhi nilai nominal dari uang, sedangkan aktivitas riil perekonomian ditentukan di sektor riil (misalnya melalui kebijakan yang dapat mempengaruhi produktivitas atau kreativitas). Namun, dalam pandangan yang lain, seringkali dikemukakan adanyatrade off antara inflasi di satu pihak dengan pertumbuhan ekonomi dan kesempatan kerja di pihak lain: jika ingin menikmati pertumbuhan ekonomi dan kesempatan kerja, makakepentingan inflasi harus sedikit dikorbankan, demikian sebaliknya. Dalam pandangan ini, kebijakan moneter yang hanya perduli pada pencapaian sasaran inflasi dikhawatirkan akan mengorbankan pertumbuhan ekonomi. Atas pandangan tersebut, pendukung sasaran tunggal inflasi cenderung menyimpulkan bahwatrade off yang mungkin terjadi hanya bersifat jangka pendek. Dalamjangka panjang, pencapaian kestabilan hargajustru akan mendukung pencapaian pertumbuhan ekonomi yang berkesinambungan.

Dalam manajemen perekonomian secara makro, seringkali pilihan kebijakan yang ditawarkan terbatas padakebijakan ekonomi makro jangka pendek yang dapatmeningkatkan permintaan agregat. Hal ini mungkin terjadi karena kebijakan ekonomi yang bersifatjangka pendek lebih menarik perhatian karena hasil yang diperoleh dapat dinikmati dengan lebih segera. Harus diakui bahwa manajemen ekonomi makro konvensional kurang menaruh 
perhatian padakendala struktural ekonomi, atau sisi penawaran dari perekonomian (supply side). Dalam konteksini, trade off di atas bisa terjadi. Dengan output potensial tertentu (given), pencapaian target pertumbuhan ekonomi yang tinggi akan dibiayai oleh tingginya laju inflasi, atau bahkan disertai memburuknya neraca pembayaran, sampai suatu tingkat yang harus dikendalikan melalui pengurangan aggregat demand - misalnya melalui kebijakan moneter ketat atau program stabilisasi ekonomi yang lain - yang memaksa perekonomian memasuki masa resesi.

Dengan kerangka pemikiran di atas, gagasan untuk menjadikan inflasi sebagai sasaran kebijakan moneter menjadi sangat relevan. Dengan sasaran inflasi yang sesuai (compatible), kebijakan moneter dapat diarahkan untuk mempengaruhi aggregat demand agar sejalan (in line) dengan kapasitas perekonomian dari sisi supply. Meski bagi kebijakan moneter inflasi merupakan sasaran akhir, dari sudut pandang manajemen ekonomi makro yang lebih luas pencapaian sasaran inflasi oleh bank sentral bukan dilihat sebagai sasaran akhir, melainkan sebagai sasaran kebijakan yang lebih segera (immediate target), yaitu sebagai barometer keberhasilan penyelarasan aggregat demand dan supply.

Pemikiran di atas, paling tidak selama dasawarsa terakhir, telah mewarnai kecenderungan bank sentral untuk memilih sasaran tunggal inflasi sebagai target kebijakan moneter. Dalam bentuknya yang paling eksplisit, sasaran tunggal tersebut diumumkan sebagai target inflasi tertentu yang harus dicapai oleh kebijakan moneter. Pencapaian target tersebut oleh bank sentral kemudian menjadi ukuran keberhasilan kebijakan moneter. Kerangka kerja tersebut dikenal sebagai inflation targeting framework. New Zealand, Canada dan Inggris (UK) sering disebut sebagai contoh negara yang menerapkan kerangka tersebut. Dalam bentuknya yang kurang eksplisit, sasaran tunggal tersebut tidak harus diumumkan sebagai target inflasi tertentu. Bank sentral cukup mengatakan stabilitas hargasebagai sasaran kebijakan moneternya. Jerman, Jepang dan A merika Serikat masuk dalam kategori ini.

M eski secara eksplisit menentukan sasaran kebijakan moneter, kerangka kebijakan moneter seperti inflation targeting tidak menentukan apa yang harus dilakukan oleh bank sentral, atau bagai mana cara mencapai target tersebut. Dalam diskusi kebijakan moneter tentang rules versus discretion misalnya, inflation targeting lebih dianggap sebagai "constrained discretion", daripada sebagai "rules" yang memberikan cara yang simpel dan mekanistis dalam hal kebijakan moneter yang harus dilakukan oleh bank sentral (Bernanke, et al., 1999). Dari pengalaman New Zealand sejak diberlakukannya inflation targeting sebagai kerangkakerja kebijakan moneter, paling tidak sudah terjadi tigakali perubahan implementasi kebijakan yang cukup mendasar.

Pembahasan tentang kerangka kebijakan moneter yang paling sesuai untuk suatu perekonomian tidak terlepas dari pemahaman tentang berlakunya mekanisme transmisi 
kebijakan moneter. Secara teoritis, terdapat beberapa alternatif jalur mekanismetransmisi, seperti jalur suku bunga, nilai tukar, harga asset, dan kredit ${ }^{1}$. Sayangnya, jal ur-jalur transmisi dari mulai instrumen sampai kepada sasaran akhir kebijakan moneter bersifat sangat kompleks dan memiliki hubungan yang kurang stabil. Beberapa ekonom bahkan mendeskripsikan proses ini sebagai suatu black box. Keterbatasan pengetahuan tentang mekanismetransmisi tersebut kemudian melahirkan pendekatan yang disebut sebagai eclectic approach dalam kerangka kebijakan moneter, seperti yang digunakan di Amerika Serikat. Dalam kerangka ini kebijakan moneter tidak disusun berdasarkan kepada jalur transmisi tertentu, misal nya dengan menggunakan target quantity atau prices, melainkan dengan melihat berbagai macam indikator yang tersedia yang digunakan untuk menghasilkan suatu assesment yang tepat untuk penentuan arah kebijakan moneter.

Kebijakan moneter di negara-negara yang menerapkan kerangka inflation targeting, akhir-akhir ini menggunakan suku bunga sebagai sasaran operasional kebijakan moneter. Respon kebijakan moneter, dalam hal ini menaikan atau menurunkan suku bunga, pada umumnya dilakukan dengan mempertimbangkan deviasi antara angka inflasi terhadap targetnya. N amun begitu, variabilitas output yang dapat terjadi dalam jangka pendek akibat suatu respon kebijakan moneter tetap diperhatikan, antara lain dengan memasukan variabel semacam output gap kedalam monetary policy reaction function. Dalam prakteknya, otoritas moneter juga akan melakukan respon atas setiap perkembangan ekonomi sepanjang hal itu akan mempengaruhi pencapaian target inflasinya.

Diskusi tentang respon kebijakan moneter di negara-negara yang menerapkan inflation targeting kembali menghidupkan debat lamatentang pendekatan rules versus discretion dalam perumusan kebijakan moneter. Pada satu sisi, penggunaan rules yang banyak mengacu kepada T aylor typerules (lihat Taylor, 1993) mendapat dukungan terutama karena dianggap dapat menjaga kredibilitas kebijakan moneter. Rules dapat dianggap sebagai suatu sistem atau perencanaan kebijakan, sehinga suatu kebijakan tidak didasarkan kepada pertimbangan yang berbeda-beda atau bahkan random, melainkan kepada aturan main yang jelas dan formal. Sementara itu pendukung pendekatan discretionary policy banyak mengacu pada adanya ketidakpastian (uncertainty) dalam praktek manajemen moneter. Dalam literatur misal nya dikenal beberapa ketidakpastian yang menyangkut mekanismetransmisi kebijakan moneter, seperti parameter uncertainty, lag uncertainty, dan uncertainty about thenature of a shock. Dengan demikian, menyerahkan respon kebijakan moneter kepada suatu rule, menurut pandangan ini, akan terlalu bersifat mekanis dan dengan sendirinya menjadi berbahaya.

1 Diskusi teoritis mengenai hal ini dapat dilihat pada Mishkin, Symposium on the Monetary Transmission Mechanism, Journal of Economic Perspectives, Fall 1995. 
Diskusi tentang respon kebijakan moneter juga menekankan pentingnya suatu kebijakan moneter yang bersifat preemptive, atau penggunaan monetary policy rules yang bersifat forward looking. Suatu kebijakan moneter baru akan mempengaruhi inflasi setelah suatu lag tertentu yang umumnya cukup panjang. Dengan demikian, respon kebijakan moneter saat ini yang ditujukan untuk mempengaruhi sasaran inflasi pada saat yang sama akan menjadi sangat terlambat dan dengan demikian tidak efektif. Dalam kerangka ini, forecast inflasi memegang peranan yang sangat penting. A pabila misal nya forecast inflasi meramal kan angka inflasi yang lebih tinggi dibandingkan targetnya, maka kebijakan moneter harus mel akukan respon berupa pengetatan moneter pada saat ini.

Sesuai dengan judulnya, paper ini akan membahas tentang kerangka kebijakan moneter dengan inflasi sebagai sasaran tungal. Pembahasan tentang inflasi apa - headline atau core inflation - yang harus digunakan, termasuk berapa tingkat inflasi yang optimal untuk dijadikan target kebijakan moneter, berada di luar lingkup pembahasan paper ini. Dengan demikian, paper ini bermaksud untuk membahas bagaimana kebijakan moneter harus dilakukan untuk mencapai sasaran tunggal inflasi ${ }^{2}$. Secara umum organisasi dari paper ini dibagi ke dalam tiga bagian besar, yang dimulai dari kerangka teori, pengujian empiris untuk kasus Indonesia, hingga akhirnya policy discussion.

Pembahasan berikut setelah bab ini akan difokuskan kepada studi literatur terkini tentang mekanisme pengendalian moneter, yang diharapkan dapat memberikan latar belakang bagi diskusi selanjutnya untuk kasus Indonesia. Diskusi teoritis terkini tentang mekanisme transmisi beserta monetary policy reaction function, khususnya dalam kerangka inflation targeting, akan dibahas dalam bab ini, disertai dengan pembahasan tentang faktor ketidakpastian yang sangat relevan dengan perumusan kebijakan moneter. Disamping itu, kerangka teori dari Poole's analysis untuk membandingkan alternatif instrumen moneter juga akan dibahas.

Pembahasan tentang hasil studi empiris mekanismetransmisi kebijakan moneter di Indonesia pada bab selanjutnya, akan mengupas beberapa saluran (channels) penting bagi kebijakan moneter dalam kerangka pencapaian sasaran tunggal inflasi. Pengujian empiris juga dilakukan atas pendekatan 0 ptimal Choice of $\mathrm{M}$ on etary $\mathrm{P}$ olicy yang dikembangkan oleh Poole(1970). Pendekatan ini pada prinsipnya mencoba memberikan landasan bagi pemilihan jenis kebijakan tertentu. Temuan empiris yang dibahas dalam bab ini akan menjadi dasar bagi penyusunan kerangka kebijakan moneter dengan inflasi sebagai sasaran tunggal.

Kemudian, berdasarkan temuan tersebut, bab berikutnya akan membahas kerangka kebijakan moneter dengan suku bunga jangka pendek sebagai target operasional yang sesuai

2 "The debate about monetary policy is not about the ends, it is about the means." (George, E., 1998) 
untuk kasus Indonesia. Disamping itu, bab ini juga akan mendiskusikan kemungkinan formulasi monetary policy reaction function yang relevan untuk kasus Indonesia. Namun, karena formulasi tersebut membutuhkan penelitian tersendiri yang mendalam, diskusi tentang policy rules dalam bab ini hanya dimaksudkan sebagai latar belakang tentang halhal yang perlu diperhatikan dalam formulasi policy rules yang relevan untuk kasus Indonesia, yaitu dengan melihat kepada berbagai alternatif yang dapat digunakan, yang pada dasarnya mengacu kepadaT aylor typerules. Dengan pertimbangan bahwa diskusi tentang policy rules yang berkembang akhir-akhir ini lebih mengarah kepada penggunaan suku bunga sebagai target operasional, dibanding agregat moneter, maka pembahasan tentang pro dan kontra penggunaan suku bunga jangka pendek tersebut penting untuk dibahas secara agak mendalam, dan akan diletakan pada awal bab ini. A khirnya, bab penutup akan menyimpulkan keseluruhan diskusi dan menwarkan beberapa rekomendasi kebijakan.

\section{Kerangka Teori Mekanisme Transmisi Kebijakan Moneter dan M onetary Policy Rule}

\section{Pendahuluan : Paradigma U ang Aktif dan U ang Pasif}

A khir-akhir ini semakin banyak bank sentral di dunia yang memfokuskan kebijakan moneter mereka pada pencapaian stabilitas harga. Walau demikian, perkembangan ini tidak mengurangi intensitas perdebatan tentang bagaimana pencapaian target tersebut dapat dilakukan. Pemahaman tentang mekanismetransmisi moneter dimaksud masih sangatjauh dari sempurna. Banyak pihak karenanya masih melihat mekanismetransmisi moneter seperti halnya sebuah black-box.

Black-box mekanisme transmisi moneter ini mendorong banyak pihak untuk mengurai dan memahami proses yang terjadi didalamnya. Secara umum terdapat dua paradigma dalam upaya memahami mekanismetransmisi moneter, yakni apa yang disebut paradigma uang pasif (passive money) dan paradigma uang aktif (active money). Perbedaan antara kedua paradigma ini dapat ditelusuri dari peran kesenjangan output (output gap) dan ekspansi likuiditas sebagai penyebab (kausal) dalam mekanismetransmisi moneter.

Paradigma uang pasif percaya bahwa kesenjangan output menjadi kausal dalam mekanismetransmisi. Dalam paradigma ini, kebijakan moneter akan mempengaruhi suku bunga jangka pendek dan nilai tukar. Perubahan suku bunga dan nilai tukar ini pada gilirannya akan mempengaruhi perkembangan besaran permintaan, kesenjangan output dan ekspektasi inflasi, dan pada akhirnya laju inflasi. Dengan kata lain, paradigma uang pasif terdiri dari kurva tabungan-investasi (IS-curve) antara kondisi moneter dan kesenjangan output, serta kurva Phillips (Phillips-curve) yang menghubungkan antara kesenjangan output dan ekspektasi inflasi dengan perubahan laju inflasi di masa mendatang. 


\section{Paradigma Uang Pasif}

Instrumen moneter (suku bunga) $\rightarrow$ suku bunga jangka pendek dan nilai tukar $\rightarrow$ besaran permintaan, kesenjangan output, ekspektasi inflasi $\rightarrow$ Inflasi.

\section{Paradigma Uang A ktif}

Instrumen moneter (besaran moneter) $\rightarrow$ target operasional (termasuk besaran moneter) $\rightarrow$ target antara $\rightarrow$ inflasi

Dalam paradigma uang pasif, variabel-variabel likuiditas seperti uang dan kredit tidak menjadi kausal dalam mekanisme transmisi moneter. Perkembangan likuiditas dari waktu ke waktu hanya menyesuaikan diri secara pasif terhadap besaran permintaan dan inflasi. Pandangan ini didasarkan pada asumsi yang menyatakan bahwa permintaan terhadap uang selalu seimbang dengan, di samping menentukan, penawaran terhadap uang. Asumsi ini dengan demikian menafikan peran kausal dari likuiditas dalam pembentukan inflasi.

Dalam hal ini, kelebihan likuiditas (excess liquidity) tidak merupakan syarat keharusan (necessary condition) bagi kenaikan inflasi, serta ekspansi likuiditas bukan merupakan syarat cukup (sufficient condition) bagi inflasi yang berkelanjutan. Paradigma ini selanjutnya hanya memperlakukan variabel-variabel moneter terbatas sebagai leading indicators dalam mekanismetransmisi.

Paradigma uang aktif sebaliknya percaya bahwa besaran likuiditas menjadi kausal, dan karenanya tidak hanya menyesuaikan diri secara pasif, dalam mekanisme transmisi moneter. Kelebihan likuiditas dan ekspansi likuiditas akan menyebabkan perilaku perekonomian yang mendorong pembentukan besaran harga. Suku bunga menurut paradigma ini hanya dipandang sebagai resultante dalam mekanisme transmisi moneter.

Paradigma uang aktif secara sederhana dapat dijelaskan dengan Teori Kuantitas Uang ( $Q$ uantity Theory of $M$ oney), yang mengacu pada persamaan berikut: $M V=P Y^{3}$. Di sini, $M$ adalah besaran moneter, $\mathrm{V}=$ vel ositas uang, $\mathrm{P}=$ tingkatharga, $\mathrm{Y}=$ tingkat ouput. $\mathrm{M}$ engingat inflasi adalah perubahan prosentase dari tingkat harga, teori kuantitas uang tidak lain merupakan sebuah teori inflasi: \% perubahan $\mathrm{M}+\%$ perubahan $\mathrm{V}=\%$ perubahan $\mathrm{P}+\%$ perubahan $\mathrm{Y}$. Teori ini dengan kata lain menyatakan bahwa bank sentral yang mengendalikan penawaran uang mem-punyai kemampuan penuh untuk mengendalikan inflasi ${ }^{4}$.

Pada awalnya, teori ini menggunakan variabel transaksi $\mathrm{T}$ instead of variabel output $\mathrm{Y}$.

Hal ini dimungkinkan setelah kita mengasumsikan bahwa velositas uang $\mathrm{V}$ adalah konstan dan tingkat output Y ditentukan di luar persamaan. Dengan asumsi dimaksud, perubahan prosentase V dan Y masing-masing adalah nol. 
Paradigma uang aktif mendasarkan pada pandangan bahwa terdapat ketidakseimbangan yang berkelanjutan antara permintaan dan penawaran uang. Sebagai konsekuensinya, perubahan harga merupakan bagian yang tidak terpi-sahkan dari proses jangka panjang untuk memulihkan keseimbangan moneter. Pandangan ini didasarkan terutama atas pemahaman tentang inter-temporal behaviour of multipleagents, ketidakpastian, dan biaya informasi (information cost).

Paradigma uang aktif, dibandingkan paradigma uang pasif, dengan demikian melibatkan sebuah perspektif tentang mekanisme transmisi moneter, khususnya yang berkaitan dengan peran likuiditas, yang lebih kompleks. Penganut paradigmaini selanjutnya berpendapat bahwa kondisi tersebut di atas sedikit banyak mendorong kecenderungan banyak pihak untuk memilih paradigma yang lebih sederhana — paradigma yang memperlakukan likuiditas sebagai variabel pasif dan semua efek-efek riil berjalan melalui hubungan kurva Phillips. ${ }^{5}$

Pencapaian konsesus dalam pilihan paradigma yang lebih baik dalam menjelaskan mekanisme transmisi moneter masih jauh dari harapan. Tiap-tiap paradigma memang membantu kita untuk lebih memahami inflasi, namun masing-masing tidak menyediakan sebuah penjelasan yang lengkap dan memuaskan tentang mekanismetransmisi moneter. Di samping itu, terdapat kecenderungan banyak pihak untuk lebih memperlakukan satu paradigma sebagai suatu substitut bagi yang lain, daripada sebagai sebuah komplemen.

Di sisi lain, kebutuhan untuk mendapatkan sebuah gambaran yang jelas dan mudah dipahami tentang mekanisme transmisi moneter semakin mendesak. Penentu kebijakan moneter sangat memerlukan sebuah policy tools yang handal dalam melaksanakan kebijakan moneter untuk mencapai target-target yang telah ditetapkan secara lebih akurat.

Babini ditujukan untuk menyediakan kerangkateoritis bagi pemahaman mekanisme transmisi kebijakan moneter dengan inflasi sebagai sasaran tunggal, di samping monetary policy rule bagi kebijakan moneter tersebut. Setelah bagian pendahuluan ini, kita akan mengulas secara ringkas apa yang disebut dengan A nal isa Poole.

Poole (1970) menggunakan model (Hicksian) ISLM untuk memecahkan masalah pemilihan instrumen moneter yang optimal, apakah itu instrumen suku bunga, besaran moneter (money stock), ataupun kombinasi keduanya. Namun hasil analisa Poole perlu diinterpretasi secara kritismengingat analisa ini pertama-tama memfokuskan pada masalah pemilihan instrumen moneter yang optimal, dan tidak secara langsung menjawab masalah paradigma apa yang lebih akurat menjelaskan masalah mekanismetransmisi moneter.

$5 \quad$ Engert dan Selody (1998) menyebut ini sebagai kecenderungan aesthetic preference for methodological simplicity 
Selanjutnya paradigma uang pasif akan dielaborasi lebih lanjut dengan perhatian khusus diberikan pada monetary policy rule untuk pelaksanaan inflation targeting ${ }^{6}$. Policy rule merupakan salah satu elemen yang inherent dalam kebijakan moneter di bawah paradigma uang pasif. Policy rulediharapkan akan memberi guidekepada penentu kebijakan dalam men-setting instrumen kebijakan dengan tujuan "mendekatkan" inflasi terhadap targetnya dengan juga memperhatikan trade-off jangka pendek antara output, kesempatan kerja dan perkembangan nilai tukar ${ }^{7}$.

Berikutnya, kita akan melihat peranan nilai tukar dalam hubungannya dengan target operasional dalam kebijakan moneter dengan sasaran inflasi-suku bunga ataupun apa yang disebut M onetary Condition Index atau MCl. Menurut Ball (1999), tidak ada penentu kebijakan di ekonomi terbuka yang dapat mengabaikan variabel nilai tukar. Taylor (1999) menyatakan bahwaTaylor's rule, yang mengabaikan variabel nilai tukar, merupakan sebuah guideline bagi A merika Serikat. Dia menambahkan bahwa ruletersebut mungkin tidak berlaku bagi negara lain, terutama bagi ekonomi kecil dan terbuka. Dalam kaitan ini, menurutnya, variabel-variabel seperti ukuran ekonomi, keterbukaan, mobilitas modal, dan elastisitas akan berperan penting.

Bagian terakhir akan secara singkat mengulas paradigma uang aktif. Namun perlu ditekankan di sini bahwa diskusi akan lebih diarahkan pada pertanyaan apakah besaranbesaran moneter hanya sebagai leading indicators atau information variables, ataukah perannya perlu dan bisa ditingkatkan menjadi instrumen atau bahkan target antara (intermediatetarget) dalam kebijakan moneter dengan inflasi sebagai sasaran tunggal.

\section{Instrumen Moneter O ptimal: Poole's Analysis}

Poole (1970) menggunakan model (Hicksian) ISLM untuk memecahkan masalah pemilihan instrumen moneter yang optimal. Masalah ini muncul karena penentu kebijakan mempunyai pilihan untuk menggunakan suku bunga ataupun besaran moneter (money stock), namun tidak kedua-duanya secara terlepas satu sama lain. Salah satu hasil temuan Pooleadalah bahwa instrumen suku bunga lebih optimal dibandingkan dengan instrumen besaran moneter untuk nilai-nilai parameter tertentu. Namun demikian untuk nilai-nilai parameter yang lain, instrumen besaran moneter sebaliknya lebih optimal.

Temuan lain menyatakan bahwa kombinasi penggunaan suku bunga dan besaran moneter sebagai instrumen moneter mungkin lebih optimal daripada penggunaan setiap instrumen secara sendiri-sendiri. Namun perlu dicatat di sini bahwa kombinasi tersebut

\footnotetext{
Kita di sini akan mengacu kepada sebuah model yang dikembangkan oleh Bank of Canada (Srour (1999). Taylor (1999)
} 
berupa sebuah hubungan yang konstan antara suku bunga dan besaran moneter. Hal tersebut terakhir, ditambah dengan prasyarat lain yang ketat dan kompleks, membuat kombinasi penggunaan instrumen moneter sulit diimplementasikan dalam praktek.

Menurut Poole, masalah pemilihan instrumen moneter tidak akan timbul apabilakita menggunakan model makroekonomi yang deterministik. Dalam model seperti ini, dengan asumsi bahwa kebijakan moneter dapat mewujudkan tingkatoutput potensial, tidak terdapat perbedaan antara kebijakan moneter dengan instrumen suku bunga maupun besaran moneter. Hal ini ditunjukkan dengan menggunakan model ISLM deterministik di bawah ini, di mana tingkat harga diasumsikan konstan.

\section{Gambar 2.}

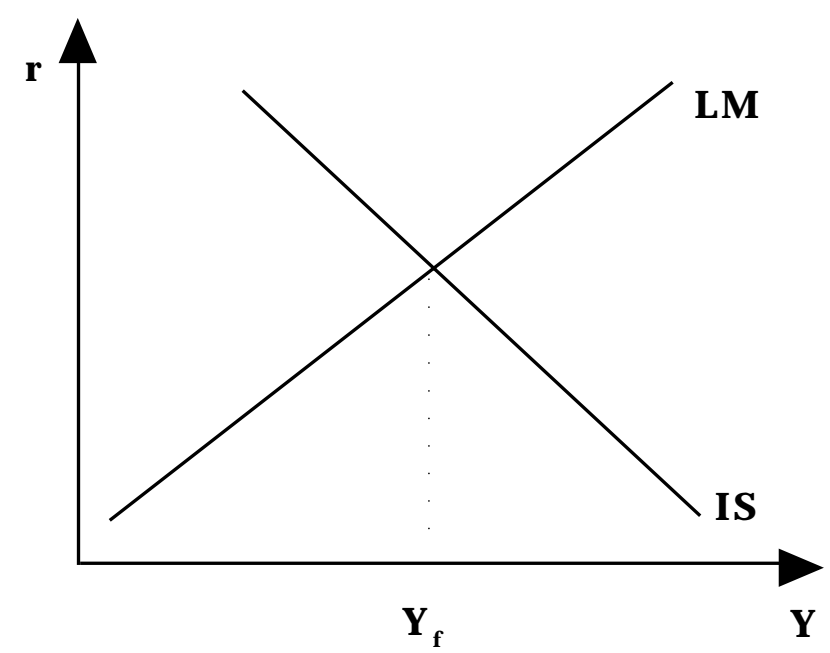

Dari Gambar 1 terlihat bahwa masalah yang dihadapi oleh penentu kebijakan adalah menentukan besaran moneter pada sebuah tingkat tertentu $(M *)$ sehingga fungsi $L M$ akan berpotongan dengan fungsi LM padatingkat output tanpa penganggguran (full employment), Yf. Sebagai alternatif, masalah kebijakan moneter dapat dilihat sebagai masalah penentuan suku bunga pada tingkat $r *$, sehingga membuat fungsi LM horizontal, untuk mewujudkan Yf (Gambar 2).

\section{G ambar 2}

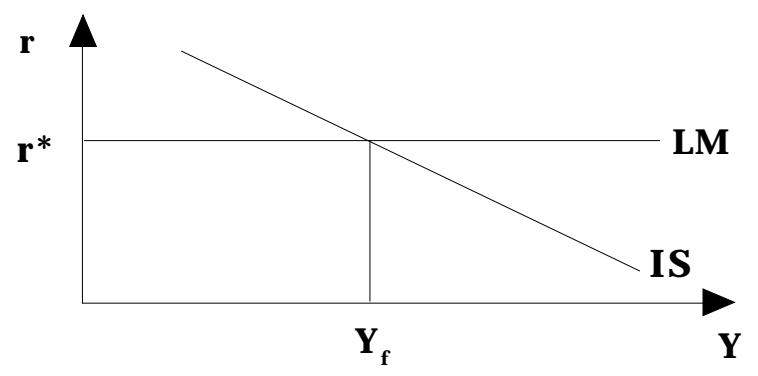


Keadaan akan lain apabila kita menggunakan model ISLM stochastic. Misalkan terjadi shocks di pasar barang sehingga membuat fungsi ISterletak di ruas IS1 dan IS2 (Gambar 3). Dengan asumsi bahwa fungsi permintaan uang adalah stabil, bila besaran moneter ditetapkan pada tingkat $\mathrm{M}$ *, fungsi LM adalah LM 1 dan karenanya output $Y$ akan terletak di ruas $Y 1$ dan Y2. N amun jika kebijakan moneter menetapkan suku bunga pada tingkat $r *$, fungsi LM akan menjadi LM 2 dan output $Y$ akan berada di ruas $Y 0$ dan $Y 3$, sebuah ruas yang lebih besar daripada ruas $\mathrm{Y} 1$ dan $\mathrm{Y} 2$. Dengan kata lain, instrumen besaran moneter akan lebih optimal daripada suku bunga dalam kasus seperti ini.

\section{G ambar 3}

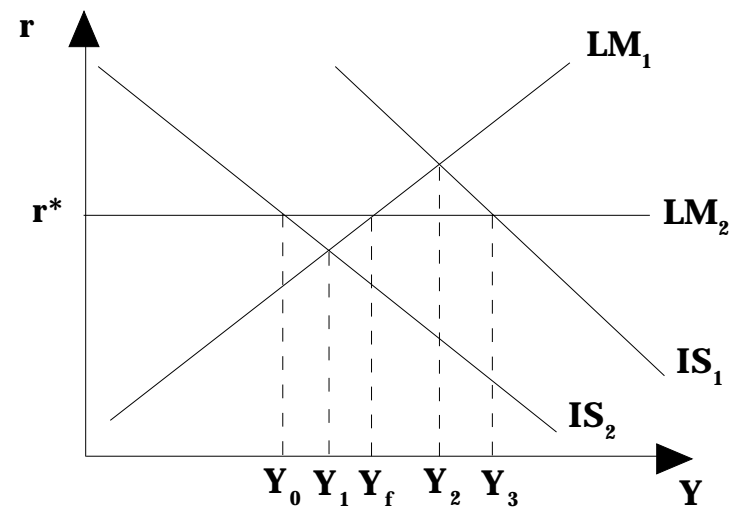

Dalam kondisi fungsi permintaan uang tidak stabil (sebagai akibat adanya shocks di pasar uang), penetapan besaran moneter pada tingkat $\mathrm{M} *$ akan menyebabkan fungsi LM berada di ruas LM 1 dan LM2, serta output $Y$ di ruas Y1 dan Y 2 (Gambar 4). Sedangkan penetapan suku bunga padar*akan menyebabkan fungsi LM dan output $Y$ masing-masing pada tingkat LM 3 dan Yf. Dapat disimpulkan bahwa instrumen suku bunga lebih optimal dalam kasus seperti ini.

\section{G ambar 4}

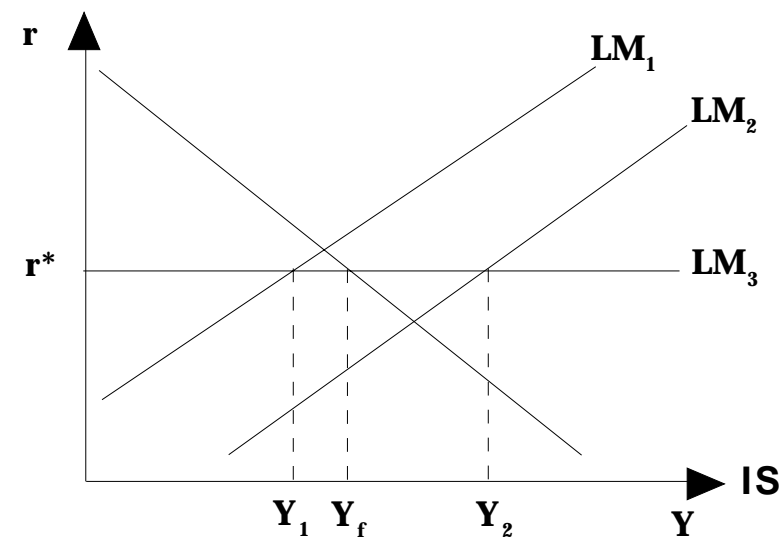


Secara umum dapat dikatakan bahwa masalah pemilihan instrumen moneter yang optimal bergantung pada arti penting dari jenis-jenis shocks pada sebuah perekonomianapakah terjadi di pasar barang atau pasar uang, serta kemiringan dari fungsi IS dan LM parameter-parameter struktural dari perekonomian tersebut. A tas dasar pemahaman tersebut, Poole mengembangkan sebuah model untuk menganalisa masalah pemilihan instrumen moneter yang optimal.

Pertama, model ISLM (H icksian), versi liniar dan non-stochastic, dapat ditunjukkan dengan persamaan (1a) dan (lb) di bawah ini:
(1a) $Y=a_{0}+a_{1} r$,
$a_{1}<0$
(lb) $M=b_{0}+b_{1} Y+b_{2} r$
$b_{1}>0, b_{2} \ll 0$

Di sini semua variabel dalam besaran riil, mengingat variabel harga diasumsikan konstan.

Persamaan (1a) dan (1b) masing-masing adalah fungsi IS dan fungsi LM. Selanjutnya juga diasumsikan bahwa parameter-parameter diketahui nilainya secara pasti dari waktu ke waktu, walau mereka dapat berubah misalnya sebagai akibat suatu kebijakan. Model mempunyai tiga variabel-Y, $\mathrm{M}$, dan r. Kebijakan moneter dengan demikian berarti memilih instrumen $M$ ataupun $r$ sehingga kita mendapatkan dua variabel endogen dan satu variabel eksogen.

Persamaan (2) dan (3) masing-masing merupakan reduced form dari instrumen suku bunga dan besaran moneter:

(2a) $Y=a_{0}+a_{1} r$

(2b) $M=b_{0}+a_{0} b_{1}+\left(a_{1} b_{1}+b_{2}\right) r$

(3a) $Y=\left(a_{1} b_{1}+b_{2}\right)^{-1}\left[a_{0} b_{2}+a_{1}\left(M-b_{0}\right)\right]$

(3b) $r=\left(a_{1} b_{1}+b_{2}\right)^{-1}\left[M-b_{0}-a_{0} b_{1}\right]$.

Dengan tingkat output padaYf, kita akan mendapatkan tingkat suku bunga optimal $r^{*}$ dan besaran moneter $M *$ dari reduced forms output $Y$, seperti terlihat dari persamaan (4) dan (5) di bawah ini:

(4) $r^{*}=a_{1}^{-1}\left(Y_{f}-a_{0}\right)$

(5) $M *=a_{1}^{-1}\left[y_{f}\left(a_{1} b_{1}+b_{2}\right)-a_{0} b_{2}+a_{1} b_{0}\right)$

Dari persamaan (2b) terlihat bahwajika suku bunga maka besaran moneter. Sedangkan jika besaran moneter maka suku bunga (persamaan (3b)). Dengan katalain, secara substansi 
tidak terdapat perbedaan antara kebijakan moneter yang menggunakan instrumen suku bunga r ataupun instrumen besaran moneter $M$.

Kedua, kita menggunakan model ISLM stochastic seperti di bawah ini:

(6a) $Y=a_{0}+a_{1} r+u$

(6b) $M=b_{0}+b_{1} Y+b_{2} r+v$

Di sini, $E[u]=E[v]=0 ; E\left[u^{2}\right]=E\left[u_{2}\right]=s_{u}^{2} ; E\left[v_{2}\right]=s_{v}^{2}$;

$\operatorname{dan} E[u v]=s_{u v}=r_{u v} S_{u} S_{v}$.

Dalam model ini, tingkat output $Y$ merupakan variabel random, dan kemungkinan distribusinya bergantung pada pilihan instrumen moneter yang digunakan.

Kriteria untuk pemilihan instrumen yang digunakan adalah instrumen apa yang meminimalkan kerugian (loss) dari kegagalan untuk menyeimbangkan tingkat output $Y$ dengan tingkat output yang diharapkan Yf. Dalam kaitan ini, fungsi kuadrat dari perkiraan kerugian (expected quadratic loss function ), $\mathrm{L}$ adalah sebagai berikut:

(7) $L=E\left[\left(y-Y_{f}\right)^{2}\right]$

Terlihat bahwajika suku bunga merupakan instrumen moneter, perkiraan kerugian minimal didapatkan bila $r=r *$ (persamaan (4)). Sedangkan besaran moneter optimal adalah $\mathrm{M}=\mathrm{M} *$ ketika besaran moneter dipilih sebagai instrumen moneter (persamaan (5)). Dengan kata lain, segera setelah instrumen moneter dipilih, model memenuhi persyaratan certainty equivalence di bawah persamaan fungsi kerugian (7). Kebijakan yang optimal dalam hal ini sama dengan kebijakan optimal pada model deterministik.

Namun demikian, kebijakan dengan instrumen suku bunga dan besaran moneter dalam model stochastic akan saling berbeda, tidak seperti halnya dengan kebijakan yang sama dalam model deterministik. Hal ini disebakan karena elemen-elemen stochastic dari reduced form $Y$ bergantung pada instrumen moneter yang digunakan. Hal tersebut dapat ditunjukkan dengan persamaan-persamaan berikut:

(8) $Y=a_{0}+a_{1} r+u=Y_{f}+u$, jikar $=r^{*}$

(9) $Y=\left(a_{1} b_{1}+b_{2}\right)^{-1}\left[a_{0} b_{2}+a_{1}\left(M-b_{0}\right)+b_{2} u-a_{1} v\right]=Y_{f}+\left(a_{1} b_{1}+b_{2}\right)^{-1}\left(b_{2} u-a_{1} v\right)$,

jika $\mathrm{M}=\mathrm{M} *$.

Dengan mensubstitusikan persamaan (8) kedalam fungsi kerugian (7), kita akan mendapatkan fungsi kerugian minimal untuk kebijakan dengan instrumen suku bunga (persamaan (10)). Sedangkan dengan mensubstitusikan persamaan (9) kedalam fungsi 
kerugian (7) kita akan mendapatkan fungsi kerugian minimal untuk kebijakan dengan besaran moneter sebagai instrumen (persamaan (11)).

$$
\begin{aligned}
& \text { (10) } L_{r}=s_{u}^{2} \\
& \text { (11) } L_{M}=\left(a_{1} b_{2}+b_{2}\right)^{-2}\left(a_{1}{ }^{2} s_{v}^{2}-2 r_{u v} a_{1} b_{2} s_{u} s_{v}+b_{2}{ }_{2} s_{u}{ }^{2}\right)
\end{aligned}
$$

Terakhir, Poole menyatakan bahwa penentu kebijakan dapat melakukan kombinasi antara suku bunga dan besaran moneter sebagai instrumen ${ }^{8}$. Kombinasi tersebut menunjukkan hubungan atau proporsi yang tetap antara kedua instrumen, seperti terlihat dari persamaan (15) di bawah ini:

(15) $C_{0} M=c_{1+} C_{2} r$.

Jika persamaan (15) ditambahkan pada model awal, kita akan mempunyai tiga persamaan dengan tiga variabel-Y, r, M. Perkiraan kerugian minimal kita dapatkan dengan melakukan turunan parsial (partial derivatives) dari fungsi kerugian terhadap c1 dan c2 dan menyetarakannya dengan nol. Al hasil, kebijakan yang optimal adalah sebagai berikut:

(16) $\mathrm{C}_{0} \mathrm{M}=\mathrm{c}_{1}{ }^{*}+\mathrm{c}_{2}{ }^{*} \mathrm{r}$

Di persamaan

$$
\text { (16), } c_{0}=b_{1} s^{2}+s_{u v^{\prime}} c_{1}^{*}=c_{0}\left(b_{0}+b_{1} Y_{f}\right)+\left(Y_{f}-a_{0}\right)\left(s^{2}+b_{1} s_{u v}\right) ; c_{2}^{*}=c_{0} b_{2}-a_{1}\left(s_{v}^{2}+b_{1} s_{u v}\right)
$$

Di bawah kebijakan kombinasi, variabel-variabel stochastic dari reduced form Y akan terpengaruh sehingga fungsi perkiraan kerugian akan terlihat seperti di persamaan (17) di bawah ini:

$$
\text { (17) Lo }=\frac{\left.s_{u} 2 s_{v}(1-r 2){ }_{u v}\right)}{s_{v}+2 r_{u v} b_{1} s_{u} s_{v}+b_{1}{ }^{2} s_{u}{ }^{2}}
$$

Dari persamaan (16) dapat diturunkan bahwa kebijakan kombinasi akan menjadi kebijakan dengan murni (pure) suku bunga sebagai instrumen ketika $\mathrm{c0}=0$. Sebaliknya, kebijakan yang sama akan menjadi kebijakan dengan murni besaran moneter sebagai instrumen ketika $c 2=0$. Poole selanjutnya juga menunjukkan bahwa kebijakan kombinasi lebih optimal daripada kebijakan dengan murni suku bunga atau besaran moneter sebagai instrumen, kecuali tentu saja pada kasus di mana salah satu dari c0 dan c2 sama dengan nol.

$8 \quad$ Poole menyatakan bahwa kita dapat memperoleh kemiringan yang optimal dari fungsi LM dengan cara membuat penawaran uang yang sensitif sekali terhadap suku bunga. 
Namun demikian, Poole mengakui bahwa keberhasilan kebijakan kombinasi bergantung pada pengetahuan kita tentang parameter-parameter model yang jumlahnya lebih banyak daripada jumlah parameter dalam kebijakan dengan murni suku bunga ataupun besaran moneter. Selain itu, dari persamaan (16) terlihat bahwa kebijakan yang optimal mungkin mensyaratkan bank sentral untuk menerapkan hubungan positif atau negatif antara $\mathrm{M}$ dan $\mathrm{r}$ mengingat $\mathrm{c} 0$ dan $\mathrm{C} 2^{*}$ dapat mempunyai tanda yang sama atau berbalikan. A tas dasar inilah kebijakan kombinasi dipandang sangat sulit dilaksanakan dalam praktek.

\section{Paradigma Uang Pasif dan Monetary Policy Rule}

Policy rule yang akan diulas di bagian ini merupakan rule untuk model ekonomi tertutup dari Srour (1999). Srour sendiri mengadopsi rule tersebut dari Ball (1997) yang telah mengembangkannya untuk model dinamis dari sebuah ekonomi tertutup. Karakteristik dinamis dari model dimaksudkan untuk menangkap fenomena di mana pengaruh perubahan suku bunga terhadap perekonomian memerlukan waktu. Selanjutnya kita juga akan melihat model dinamis untuk sebuah ekonomi kecil dan terbuka, yang merupakan pengembangan model ekonomi tertutup di mana variabel nilai tukar menjadi variabel tambahan.

\section{Model Dasar (Benchmark)}

Mekanisme transmisi moneter bagi sebuah ekonomi tertutup berturut-turut dapat direpresentasikan dengan accel erationist Phillips curvedan IS curve seperti berikut:

(18) $\mathrm{p}_{\mathrm{t}+1}=\mathrm{p}_{\mathrm{t}}+\mathrm{d}\left(\mathrm{y}_{\mathrm{t}}-\mathrm{y}^{*}\right)+\mathrm{e}_{\mathrm{t}+1}$

(19) $y_{t+1}-y^{*}=b\left(y_{t}-y^{*}\right)-c\left(r_{t}-r^{*}\right)+h_{t+1}$

Semua variabel dalam logaritma.

Di sini, yt adalah besaran output; $y^{*}$ adalah output potensial (diasumsi kan konstan); pt adalah tingkat inflasi; it adalah instrumen kebijakan moneter (di identifikasikan dengan suku bunga nominal untuk satu periode); rt adalah suku bunga riil, yakni rt $\cong i t-p t+1 \mid t$, di mana $\mathrm{pt}+1$ | tadalah perkiraan tingkat inflasi pada periodet +1 berdasar informasi yang ada pada periodet; $r^{*}$ adalah rata-rata suku bunga riil (juga diasumsikan konstan); b,c, dan d merupakan konstanta-konstanta positif, dengan $b<1$; et dan ht merupakan whitenoiserandom shocks.

Karakteristik utama dari model di atas adalah bahwa pengaruh suku bunga pada inflasi dicapai melalui besaran kesenjangan output. Dengan demikian, sebuah kebijakan moneter mempengaruhi inflasi dengan lag dua periode. Hal ini kurang lebih sesuai dengan fakta-fakta empiris yang ditemui di sejumlah negara penganut inflation targeting seperti Kanada dan Inggris. 


\section{Loss Function}

Mengikuti kelaziman, di sini diasumsikan bahwa penentu kebijakan dalam setiap periodememinimalkan discounted sum dari perkiraan (weighted) deviasi output dan inflasi dari target.

(20) $E_{t} S \sum_{i=0}^{\infty} \delta^{i} L\left(\pi_{t+1}, Y_{t+1}\right)$

Di mana,

(21) $L(\pi, y)=a\left(y-y^{*}\right)^{2}+(1-a)\left(\pi-\pi^{*}\right)^{2}$

dan dengan $0 \leq \alpha \leq 1$ dan $0 \leq \delta \leq 1$. Semakin d mendekati 1 , semakin besar bobotyang diberikan pada biaya jangka panjang. Pada limit $\delta=1$, hanya biaya jangka panjang yang berpengaruh, sehingga persamaan (21) dapat diidentifikasikan sebagai perkiraan unconditional $\mathrm{EL}(\pi \mathrm{t}, \mathrm{yt})$.

\section{Optimal Rule}

Mengingat problem optimisasi di atas memenuhi apa yang disebut persyaratan certainty-equivalence, meminimalkan perkiraan deviasi seperti ditunjukkan oleh persamaan (21) setara dengan meminimalkan deviasi perkiraan, seperti ditunjukkan oleh persamaan berikut:

$$
\text { (22) } \sum_{\mathrm{i}=0}^{\infty} \delta\left[\alpha\left(\mathrm{E}_{\mathrm{t}} \mathrm{y}_{\mathrm{t}+1}-\mathrm{y}^{*}\right)+(1-\alpha)\left(\mathrm{E}_{\mathrm{t}} \pi_{\mathrm{t}+1}-\pi^{*}\right)^{2}\right]
$$

Dari persamaan (22) dapat disimpulkan bahwa jika bank sentral sepenuhnya mentargetkan inflasi $(\alpha=0)$, maka hanya deviasi perkiraan inflasi terhadap target yang berpengaruh. Mengingat instrumen moneter hanya dapat mempengaruhi inflasi dengan lag selama dua periode, policy ruleyang optimal dalam kasus ini adalah penetapan suku bunga pada setiap periode sehingga perkiraan inflasi dalam dua periode kedepan setara dengan target:

$$
\text { (23) } \pi_{\mathrm{t}+2 \mid \mathrm{t}}=\pi^{*}
$$

Dari persamaan (18) dan (19), $\pi_{\mathrm{t}+2 \mid \mathrm{t}}$ dapat dijelaskan sebagai fungsi dari statevariables dan instrumen kebijakan moneter pada periodet,

$$
\text { (24) } \pi_{\mathrm{t}+2 \mid \mathrm{t}}=\pi_{\mathrm{t}+1 \mid \mathrm{t}}+\mathrm{db}\left(\mathrm{y}_{\mathrm{t}}-\mathrm{y}^{*}\right)-\mathrm{dc}\left(\mathrm{r}_{\mathrm{t}}-\mathrm{r} *\right)
$$

Policy rule seperti ditunjukkan dalam persamaan (23) dapat dijelaskan dengan kalimat berikut. Jika perkiraan inflasi untuk dua periode kedepan (lihat persamaan (24)), 
lebih tinggi daripada target, maka suku bunga akan dinaikkan sehingga output pada periode $t+1$ lebih rendah daripada tingkat potensialnya dan karenanya menurunkan inflasi pada periodeberikutnya $(\mathrm{t}+2)$.

Di sisi lain, jika bank sentral hanya menganggap stabilitas output sebagai satu-satunya target $(\alpha=1)$, maka bank sentral tersebut akan menetapkan suku bunga pada setiap periode sehingga perkiraan output pada periode berikut setara dengan output potensial. Dalam kasusini, inflasi akan mengikuti pola random walk sebagai berikut:

(25) $\pi_{\mathrm{t}+2 \mid \mathrm{t}}=\pi_{\mathrm{t}+1 \mid \mathrm{t}}+\varepsilon_{\mathrm{t}+2}+d \eta_{\mathrm{t}+1}$

Pada prakteknya, bank-bank sentral dengan target inflasi memperhatikan baik variabilitas output maupun inflasi $(0<\alpha<1)$. Policy rule yang optimal dengan demikian adalah:

(26) $\pi_{\mathrm{t}+2 \mid \mathrm{t}}-\pi^{*}=\mathrm{k}\left(\pi_{\mathrm{t}+1 \mid \mathrm{t}}-\pi^{*}\right)$

Konstanta k mempunyai nilai antara 0 dan 1 , serta meningkat seiring dengan peningkatan nilai $\alpha$.

Persamaan (26) dapat dijelaskan dengan Kurva Phillips. Kurva ini mengisyaratkan bahwa terdapat trade-off jangka pendek antara output dan inflasi-penurunan inflasi memerlukan kesenjangan output negatif yang bersifat sementara. Jika tidak ada bobot diberikan pada stabilitas output $(\alpha=0)$, bank sentral akan berusaha untuk mencapai target inflasi secepat mungkin $(k=0)$, tetapi dengan konsekuensi berupa fluktuasi output yang besar.

Namun jika bobot positif diberikan padastabilitas output $(\alpha>0)$, setelah sebuah shock terjadi, bank sentral menurunkan inflasi keposisi semula secara bertahap $(k>0)$ dalam rangka mengurangi fluktuasi output-semakin besar bobot a dibebankan pada stabilitas output, semakin besar koefisien $\mathrm{k}$ dan semakin lama (gradual) penyesuaian inflasi berlangsung. Terakhir, jika bank sentral hanya mentargetkan output $(\alpha=1)$, inflasi mengikuti random walk $(k=1)$.

Dari persamaan (18), (19), dan (26), kita dapat memperoleh sebuah policy rule seperti terlihat di persamaan (10) di bawah ini:

(27) $r t-r^{*}=B\left(y_{t}-y^{*}\right)+C\left(p_{t}-p^{*}\right)$

Di sini,

$$
B=\frac{1-k+b}{c}>0, \text { dan } C=\frac{1-k}{c d}>0
$$


Ruleyang sama selanjutnya dapat ditulis seperti persamaan (11) berikut:

(28) $\mathrm{i}_{\mathrm{t}}-\mathrm{i}^{*}=\mathrm{B}^{\prime}\left(\mathrm{y}_{\mathrm{t}}-\mathrm{y}^{*}\right)+\mathrm{C}^{\prime}\left(\pi_{\mathrm{t}}-\pi\right)$

Di sini $\mathrm{B}^{\prime}=\mathrm{B}+\mathrm{d}>0, \mathrm{C}^{\prime}=\mathrm{C}+1>1$, dan $\mathrm{i}^{*}=\pi^{*}+\rho^{*}$. Persamaan (10) dan (11) merupakan sebuah policy rule yang mensyaratkan peningkatan (penu-runan) suku bunga (riil atau nominal) ketika tingkat output atau inflasi berada di atas (bawah) target-target yang ditetapkan.

Sejauh ini pengulasan policy rulemasih terbatasuntuk kasus ekonomi tertutup. Bagian berikut secara khusus akan mengupas sebuah model untuk ekonomi kecil dan terbuka. M odel tersebut dikembangkan oleh Ball (1999) dan terdiri atas tiga persamaan berikut:

(29) $\pi_{\mathrm{t}+1}=\pi_{\mathrm{t}}+\mathrm{d}_{\mathrm{yt}}-f\left(\mathrm{e}_{\mathrm{t}}-\mathrm{e}_{\mathrm{t}-1}\right)=\eta_{\mathrm{t}+1}$

(30) $\mathrm{y}_{\mathrm{t}+1}=\mathrm{by}_{\mathrm{t}}-\mathrm{cr}_{\mathrm{t}}-\mathrm{ge} \mathrm{t}_{\mathrm{t}}+\eta_{\mathrm{t}+1}$

(31) $e_{t}=h r_{t}+v_{t}$

Di sini, et adalah nilai tukar riil (peningkatan e berarti apresiasi), dan $\varepsilon, \eta, v$ merupakan white noise shocks. Di samping itu, semua variabel direpresentasikan sebagai deviasi dari nilai rata-rata mereka.

Model di atas tidak lain merupakan model dasar (untuk ekonomi tertutup) dengan nilai tukar sebagai variabel endogen baru. Nilai tukar berpengaruh pada besaran permintaan di masa datang melalui variabel ekspor, sedangkan perubahan nilai tukar berpengaruh pada inflasi di masa datang melalui variabel harga impor (harga dalam negeri berubah dengan lag satu periode). Shocks nt dimaksudkan untuk menangkap perubahan ekspektasi dan kepercayaan pasar.

Dengan mengasumsikan adanya kondisi unconditional $(d=1)$ dari persamaan (20), kita akan dapat memperoleh sebuah policy ruleyang optimal seperti terlihat di persamaan berikut:

(32) $w r_{t}+(1-w) e_{t}=A y_{t}+b\left(p_{t}+f e_{t-1}\right)$

, untuk sejumlah nilai positif dari konstanta w, $A$ dan $B(0<w<1)$.

Penggalan wrt + (1 - w)et dapat dipandang sebagai apa yang disebut monetary conditions index $(\mathrm{MCl})$. Sedangkan pt+fet-1 dimaksudkan sebagai ukuran inflasi yang telah mengeluarkan dampak langsung namun temporer dari pergerakan nilai tukar. Dengan demikian, policy rule yang optimal mensyaratkan pengetatan kondisi moneter (yang tercermin dari perubahan $\mathrm{MCl}$ ) pada waktu terjadi peningkatan kesenjangan output atau inflasi, namun mempertahankan kondisi moneter pada waktu terjadi perubahan nilai tukar yang bersifat temporer. 
Ball selanjutnya juga menunjukkan bahwa bobot relatif dari suku bunga dan nilai tukar dalam $\mathrm{MCl}$ kurang lebih sama dengan apa yang terdapat pada kurva IS, yakni tiga berbanding satu. Intuisi untuk ini menyatakan bahwastabilisasi output dan harga terutama dicapai melalui pengendalian besaran permintaan. Di sisi lain, meskipun kebijakan moneter dapat mempengaruhi inflasi secara langsung melalui (kebijakan) nilai tukar, langkah ini memerlukan variabilitas suku bunga yang signifikan dan fluktuasi output yang besar sebagai konsekuensinya.

\section{Variabel Nilai Tukar dan Target 0 perasional}

Secara umum target operasional dalam kerangka inflation targeting dapat dibedakan antara target suku bunga (persamaan (27)) atau $\mathrm{MCl}$ (monetary condition index) seperti yang terlihat pada persamaan (32). Namun demikian, dengan modifikasi aljabar sederhana, persamaan (32) dapat diperlakukan sebagai persamaan (32) $w r_{t}+(1-w) e_{t}=A y_{t}+B\left(p_{t}+f e_{-1}\right)$ suku bunga sebagai berikut:

$\left(32^{\prime}\right) w r_{t}=A y_{t}+B\left(p_{t}+f e_{t-1}\right)-(1-w) e_{t}$

Dari persamaan (32) maupun (32') terlihat bahwa variabel nilai tukar diperhi-tungkan baik dalam persamaan suku bunga maupun $\mathrm{MCl}$. Walau persamaan (32) dan (32') mempunyai kemiripan, namun secara teknis terdapat perbedaan yang mendasar antara keduanya. Pihak yang mentargetkan suku bunga memandang variabel nilai tukar sebagai sebuah variabel yang mempengaruhi posisi kebijakan yang optimal, sedangkan pihak dengan target $\mathrm{MCl}$ memperlakukan variabel nilai tukar sebagai bagian dari definisi kebijakan.

Di samping itu, pilihan target operasional dalam prakteknya dapat mempunyai konsekuensi kebijakan moneter yang berbeda, walaupun perbedaan tersebut secara teoritis mungkin tidak ditemui (Ball, 1999). Secara teoritis, kedua persamaan, misalnya, akan menyatakan bahwa penurunan e (depresiasi), untuk $r$ tertentu, akan mensyaratkan kenaikan suku bunga r. Penentu kebijakan dengan target operasional $\mathrm{MCl}$ akan berargumen bahwa kenaikan $r$ akan mempertahankan posisi kebijakan, sedangkan pihak dengan target suku bunga akan mengatakan bahwa kenaikan r diperlukan untuk menyedot likuiditas akibat depresiasi.

Secara teoritis, kesamaan konsekuensi kebijakan antara keduanya disebabkan karena instrumen moneter dapat diubah seketika ke tingkat yang optimal setelah sebuah shock terjadi. Namun dalam prakteknya, penentu kebijakan hanya dapat mengubah instrumen moneter secara bertahap. Hal tersebut terakhirlah yang mendorong perbedaan konsekuensi kebijakan antara kedua target operasional tersebut.

Ball menyebut dua al asan mengapa instrumen moneter tidak berubah seketika. Pertama, evaluasi kebijakan tidak secara terus-menerus (continue) oleh bank sentral, namun secara 
periodik. Dalam kaitan ini, setting kebijakan dianggap konstan dalam periode tertentu, misalnya satu kuartal. Dengan demikian, di dalam suatu kuartal, target operasional suku bunga mengimplikasikan suku bunga konstan, sedangkan target $\mathrm{MCl}$ mengimplikasikan perubahan suku bunga dalam upaya untuk "menangkap" pergerakan nilai tukar.

Kedua, penentu kebijakan secara umum enggan (reluctant) untuk mengubah instrumen moneter secara signifikan. Dalam kasus suku bunga sebagai target operasional, keengganan penentu kebijakan untuk mengubah instrumen moneter-walau keadaan sebenarnya memerlukan perubahan yang signifikan-sering disebut dengan interest rate smoothing. Sedangkan keengganan untuk mengubah target operasional $\mathrm{MCl}$ dapat disebut $\mathrm{M} \mathrm{Cl}$ smoothing.

Dengan adanya instrument smoothing, pi hak-pihak yang mentargetkan suku bunga dan $\mathrm{MCl}$ akan mempunyai reaksi yang berbeda terhadap shocks. Seperti kasus penurunan euntuk tingkat $r$ tertentu terdahulu, sebuah shocks akan mendorong kenaikan $r$ baik dalam target operasional suku bunga maupun $\mathrm{MCl}$. Namun demikian, instrument smoothing mengerem kenaikan suku bunga dalam target operasional suku bunga. Mengingat penyesuaian suku bunga tidak memerlukan perubahan dalam $\mathrm{MCl}$, perilaku $\mathrm{MCl}$ praktistidak terpengaruh oleh adanya shocks. Dengan kata lain, untuk kasus ini, target operasional $\mathrm{MCl}$ mensyaratkan kebijakan yang lebih kontraktif daripada suku bunga sebagai target operasional.

Menjadi pertanyaan menarik adalah apakah kita bisa mengatakan bahwa suatu target operasional secara umum lebih optimal dibandingkan target operasional yang lain, ataukah hal tersebut hanya berlaku khusus bagi sebuah perekonomian tertentu. Ball (1999) mengatakan bahwa pilihan target operasional yang optimal bergantung pada pengaruh dua jenis shocks, yakni net-export dan net-foreign-investment shocks.

Ditambahkannya, pilihan yang optimal kemungkinan berbeda untuk perekonomian yang berbeda. Target operasional suku bunga lebih optimal bagi sebuah ekonomi di mana shocks eksternal didominasi oleh perubahan dalamnet-foreign-investment. Sebaliknya, shocks eksternal terhadap net-export akan lebih memberi tempat pada target operasional $\mathrm{MCl}$.

Selain berpengaruh melalui jalur besaran permintaan, seperti ditekankan pada uraian sebelum ini, shocks eksternal terhadap nilai tukar juga berpengaruh langsung pada kestabilan inflasi. Menjadi pertanyaan, misalnya, apakah depresiasi nilai tukar harus direspons dengan kenaikan r sehingga pertumbuhan output yang lebih rendah akan menekan efek inflasi dari depresiasi. Jawaban atas pertanyaan ini bergantung pada apakah shocks tersebut menyebabkan nilai tukar riil dari sebuah perekonomian mengalami pergeseran dari tingkat equilibrium jangka panjang, ataukah hanya dari tingkat jangka pendeknya? .

$9 \quad$ Ball (1999) 
Dengan mengacu pada persamaan (32) wrt $+(1-w)$ et $=A y t+b(p t+f e t-1), p t=f e t-1(=p *)$ adalah ukuran inflasi yang telah mengeliminasi efek fluktuasi nilai tukar jangka pendek. Bila nilai tukar mengalami depresiasi (temporer) namun tingkat equilibrium jangka panjangnya tidak berubah, maka inflasi IHK akan meningkat namun p*tidak terpengaruh. Mengingatp*tidak mengalami peningkatan, kebijakan pengetatan moneter tidak diperlukan. Kebijakan pengetatan sebaliknya diperlukan apabila nilai tukar riil mengalami depresiasi yang bersifat permanen.

\section{Besaran Moneter: Leading Indicators atau Target Antara?}

Fungsi besaran-besaran moneter dalam kebijakan moneter dengan inflasi sebagai sasaran akhir beragam dari satu negara kenegara lain. Besaran moneter, misal nya, semakin ditinggalkan sebagai guides kebijakan moneter di Amerika Serikat terutama dengan pertimbangan ketidakstabilan velositas dan inovasi finansial yang sangat pesat. Sedangkan negara-negara yang menerapkan inflation targeting - seperti Kanada, Selandia Baru, dan Inggris-memperlakukan besaran-besaran moneter terbatas sebagai variabel informasi (information variable). Di sisi Iain, Bank Sentral Eropa telah menyeleksi sejumlah besaran moneter dal am arti luas (broad money) untuk di monitor dalam pelaksanaan kebijakan moneter mereka.

Penelitian yang dilakukan oleh Estrella dan Mishkin (1996)—dengan menggunakan data empiris A merika Serikat sejak 1979-menunjukkan bahwa besaran-besaran moneter tidak memenuhi persyaratan (secara statistik) dalam fungsinya masing-masing sebagai variabel informasi (information variable), indikator kebijakan, ataupun instrumen kebijakan moneter. Fungsi-fungsi tersebut berturut-turut mensyaratkan hubungan statistik yang semakin kuat dan stabil antara besaran moneter dan target-target akhir kebijakan. Penelitian mereka yang menggunakan data empiris untuk Jerman juga menunjukkan hasil yang konsisten.

Namun hasil penelitian ini, menurut mereka, sama sekali tidak menafikan fungsi besaran moneter sebagai variabel informasi-walau dalam bentuk yang tidak sederhana. Hanya hasil dimaksud mengindikasikan bahwa besaran moneter tidak dapat digunakan secara langsung untuk tujuan-tujuan kebijakan moneter. A kibatnya, mereka tidak dapat berfungsi baik sebagai signal kebijakan moneter, sesuatu yang menjadi prasyarat penting bagi pelaksanaan kebijakan moneter di bawah kerangka money targeting.

Masalah utama penggunaan besaran moneter sebagai anker (guideline) bagi kebijakan moneter adalah ketidakstabilan velositas. Ketidakstabilan ini pada gilirannya mendorong perubahan hubungan antara pertumbuhan uang dan output nominal dalam fungsi permintaan uang. Masalah ini semakin relevan di sebuah sistim di mana perubahan output nominal, inflasi ataupun penawaran uang relatif kurang signifikan. Di sistim seperti itu, 
rasio antara signal dan gangguan (noise) kemungkinan besar akan bernilai rendah. Hal tersebut terakhir membuat besaran moneter bukan sebuah guideyang handal bagi kebijakan moneter.

Di sisi lain, seperti pendukung paradigma uang aktif lainnya, Laidler (1999) berpendapat bahwa likuiditas mempunyai peran kausal dalam mekanismetransmisi moneter. Atas dasar ini, dia secara khusus menyatakan bahwa paradigma uang aktif harus diperlakukan sebagai komplemen, dan bukannya substitusi, bagi paradigma uang pasifyang semakin luas menjadi kerangka teoritis bagi kebijakan moneter dengan sasaran inflasi.

Usulan Laidler ini didasarkan pada sejumlah argumen. Pertama, Laidler berpendapat bahwa paradigma uang aktif lebih masuk akal (plausible), baik secara teoritismaupun empiris. Pengalaman-pengalaman yang kurang menguntungkan dengan pentargetan kuantitas tidak sepenuhnya berasal dari besaran likuiditas itu sendiri, namun sebagian berasal dari kelemahan mekanismeyang ada untuk mengontrol pertumbuhan besaran ini.

A rgumen kedua berkaitan dengan pandangan kritis mengenai ketidakstabilan fungsi permintaan uang. Menurutnya, keberadaan fungsi permintaan uang yang tidak stabil, baik yang disebabkan oleh perubahan institusional maupun oleh hal lain, tidak layak menafikan arti penting dari interaksi antara fungsi permintaan uang dan fungsi penawaran uang dalam menentukan besaran permintaan.

Hanya memang ketidakstabilan fungsi permintaan uang membuat penerapan mekanisme ini kedalam kerangka kebijakan moneter jauh dari mudah. Menyikapi hal ini, dia berpendapat bahwa ketika kita mengamati perilaku uang atau likuiditas, kita perlu mengenali waktu terjadinya perubahan dan membuat penyesuaian yang diperlukan. Namun demikian, tambahnya, perilaku likuiditasitu sendiri tetap relevan. $\mathrm{H}$ al ini mengingat bahwa interaksi antara permintaan dan penawaran uang sangat penting artinya bagi kebijakan moneter, dan juga bagi proses-proses lainnya dalam perekonomian.

Berdasar argumen-argumen di atas, Laidler akhirnya mengajukan usulan bagi bank sentral untuk menggunakan tingkat pertumbuhan dari (satu atau lebih) besaran moneter dalam kebijakan moneter mereka. Besaran-besaran moneter tersebuttidak difungsikan sebagai satu-satunya target moneter, akan tetapi lebih sebagai sebuah target antara pelengkap (complementary intermediate target) di tengah-tengah target-target antara yang lain. Namun perlu dicatat di sini bahwa Laidler tidak mengungkapkan dengan konkret bagaimana caranya menjadikan besaran moneter sebagai suatu target antara ataupun operasional ${ }^{10}$.

10Menurut Laidler, keberhasilan upaya dimaksud sangat bergantung pada tingkat kemudahan besaran-besaran moneter tersebut untuk dikendalikan (controlability) oleh bank sentral. 
Dengan menggunakan data empiris Kanada, McPhail (1999) melakukan penelitian tentang hubungan antara besaran moneter (dal am pengertian luas) dengan inflasi di Kanada. Menurutnya, arti penting besaran moneter sebagai suatu variabel kebijakan moneter bergantung pada dua hal. Pertama, terdapat fungsi permintaan uang yang stabil padajangka panjang. Kedua, besaran moneter merupakan indikator yang handal bagi inflasi dalam jangka waktu satu atau dua tahun kedepan. McPhail mempunyai proposisi bahwa bila kedua hal tersebut di atas didukung oleh data empiris, dapat disimpulkan bahwa besaran moneter dalam arti luas (M2) merupakan sebuah variabel kebijakan moneter yang berguna.

Hasil penelitiannya mendukung proposisi tersebut di atas. Fungsi permintaan uang cenderung stabil di jangka panjang ${ }^{11}$. Dalam periode yang diteliti, tidak terdapat ketidakstabilan fungsi permintaan uang yang signifikan. Di samping itu, penelitiannya juga menunjukkan bahwa besaran moneter dalam arti luas (M2) merupakan indikator inflasi pada jangka panjang yang handal. Khususnya, model yang mengikutsertakan M2 menghasilkan forecast inflasi yang lebih akurat dibandingkan dengan model yang mengabaikannya.

Dari diskusi di atas terlihat bahwa fungsi besaran moneter baik sebagai instrumen maupun target antara atau operasional dalam kebijakan moneter dengan sasaran inflasi semakin ditinggalkan di banyak negara. N amun demikian, besaran-besaran moneter dalam fungsinya sebagai variabel informasi masih memberikan kontribusi penting bagi kebijakan moneter dalam kerangka inflation targeting.

Secara umum terdapat dua pertimbangan utama mengapa penentu kebijakan perlu memonitor perkembangan besaran moneter (dan kredit bank) $)^{12}$. Pertama, shocks terhadap besaran pengeluaran (spending) dapat berasal dari sektor perbankan. Hal ini berkaitan dengan apa yang disebut dengan bank lending channel, yakni efek-efek yang berasal dari sektor perbankan yang mendorong perubahan perilaku pengeluaran yang tidak secara langsung disebabkan oleh perubahan suku bunga. Fenomenacredit crunch merupakan contoh yang tepat untuk ini. Dalam fenomena ini, penurunan volume kredit bank secara drastis didorong oleh kerugian modal (capital loss) sebagai akibat kredit macet ataupun kebijakan kontraksi.

Kedua, seperti tersebut terdahulu, fungsi permintaan uang cenderung stabil di jangka panjang. Dengan kata lain, di jangka panjang terdapat hubungan positif antara besaran moneter dan tingkat harga-harga. Dalam arti, kenaikan harga yang berkelanjutan tidak mungkin terjadi tanpa disertai pertumbuhan dalam besaran-besaran moneter. Dengan

11 McPhail menggunakan data berjangka waktu 30 tahun.

12 Bank of England (1999) 
demikian, monitoring perkembangan besaran moneter akan memberikan informasi dan indikasi yang berharga bagi pemahaman tentang inflasi di masa datang.

\section{Pengujian Empiris Transmisi Kebijakan Moneter di Indonesia}

Pembahasan dalam bab ini akan mengkaji pengaruh kebijakan moneter terhadap Inflasi di Indonesia, terutama berkaitan dengan pengujian empiris jalur-jalur (channels) transmisi kebijakan moneter yang berlaku di Indonesia, dan berapalama kebijakan moneter ditransmisikan melalui jalur-jalur tersebut hingga mencapai sasaran akhir inflasi. Alat analisis yang digunakan untuk pengujian empiris adalah beberapa untuk menguji keterkaitan antar variabel dalam jalur-jalur transmisi dan pengujian Poole's A nalysisuntuk membandingkan pendekatan kebijakan moneter berdasarkan agregat moneter dan suku bunga.

Teknik timeseries econometric yang digunakan meliputi $\mathrm{H}$ siao-G ranger causality untuk mengetahui hubungan kausalitas antar variabel moneter, cointegration test untuk menguji hubungan antar variabel dalam jangka panjang, dan aplikasi metode vector autoregression (VAR) untuk mengetahui hubungan transmisi secara keseluruhan, termasuk policy lags dalam setiap jal ur transmisi. Secara lebih detail aplikasi VA R tersebut meliputi variancedecomposition dan grafik impulse responsefunction. Sementara itu Poole's A nalysis secara empiris menguji O ptimal Choice of M onetary Policy yang dikembangkan oleh Poole (1970). Pendekatan ini pada prinsipnya mencoba memberikan landasan bagi pemilihan jenis kebijakan tertentu dengan dasar minimi sasi expected loss dari output

Dalam pengujian ini, inflasi yang digunakan adalah core (underlying) inflation yang didapatkan dengan metodepercentiletrimmed mean ${ }^{13}$. Pertimbangan utamanya adalah inflasi tersebut yang paling relevan untuk kebijakan moneter, karena pada inflasi tersebut pengaruh noise yang berasal dari supply shocks sudah dieliminir. Variabel lain yang diperoleh dari hasil generete data awal adalah output gap. Output gap diperoleh dari hasil pengurangan PDB aktual dengan PDB potensial. Dalam hal ini, trend dari PDB aktual - dihitung dengan menggunakan metode Hendrick Prescott Filter - digunakan sebagai proksi untuk PDB potensial

\section{Kerangka Hipotesis Mekanisme Transmisi Kebijakan Moneter}

Secarateoritis, mekanismetransmisi kebijakan moneter dapat dibedakan menjadi dua jalur; pricechannel dan quantity channel. Transmisi melalui pricechannel dapat dibedakan lagi

13 Dari hasil perhitungan, kombinasi antara percentile ke-77 dengan pemangkasan (trim) sebesar 20\% menghasilkan core inflation yang paling robust untuk kasus Indonesia. Artinya, dari 662 jenis barang dalam keranjang IHK, 102 perubahan harga terendah dan 30 perubahan harga tertinggi diberi bobot nol karena dianggap tidak mewakili kecenderungan perubahan harga secara umum (Tim Inflation Targeting, Bank Indonesia, 1999). 
menjadi tiga kategori; channel exchange rate, interest rate, dan assets price, sementara quantity chanel meliputi monetary channel dan credit channel. Dalam pada itu, perbedaan struktur perekonomian, perkembangan pasar keuangan dan sistem nilai tukar yang dianut akan menyebabkan transmisi kebijakan moneter masing masing-masing negara berbeda satu sama lainnya.

Untuk pengujian empiris kasus Indonesia, mekanismetransmisi kebijakan moneter hipotesis dibedakan kedalam dua jal ur. Jalur quantity channel ${ }^{14}$ diawali dengan perubahan pada basemoney (sebagai operational target) à uang beredar à inflasi (underlying). Sementara itu pada jalur price channel transmisi dimulai dari suku bunga SBI (policy instrument)à very short term interest rate(PUABO/ N) àlonger term interest rate(Deposito) dan Nilai Tukar (Riil) à Output Gap à Inflasi (underlying).

\section{Pengujian Jalur Q uantity (Active Money Approach)}

Prisip dasar pendekatan kuantitas (active money approach) mengacu pada persamaan identitas MV = PT yang berarti bahwa jumlah uang beredar dikalikan dengan vel ocity-nya akan sama dengan hasil perkalian harga dengan volume transaksi dalam suatu perekonomian. Persamaan tersebut dapat dipandang sebagai gambaran dari keterkaitan hubungan antara sektor moneter dengan sektor riil. Kebijakan moneter dalam pendekatan ini berusaha mengendalikan jumlah uang beredar $(M)$ untuk mempengaruhi sektor riil ( $P$ dan T). Secara lebih teknis, bank sentral berusaha mencapai target operasional uang primer (M0), dimana dengan asumsi money multiplier tertentu yang predictable, pencapaian target M Oakan mempengaruhi jumlah uang beredar, baik M 1 maupun M2, yang kemudian akan berpengaruh terhadap laju inflasi. Dari gambaran tersebut, pendekatan ini mensyaratkan adanya velocity dan money multiplier yang bersifat stabil, atau paling tidak predictable, sehingga Bank Sentral akan mengetahui seberapa besar pengaruh perubahan base money, baik terhadap Uang Beredar (M2/ M 1) maupun terhadap laju inflasi.

Dengan maksud mengevaluasi hubungan antar variabel tersebut, telah dilakukan uji H siao-granger causality dengan menggunakan data bulanan 1990-1999. Hasil pengujian dapat dilihat pada tabel 1.

14 Secara official Bank Indonesia masih menggunakan quantity approach, dimana dalam perkembangannya pendekatan ini tidak lagi digunakan secara utuh akan tetapi dikombinasikan dengan price approach. 
Tabel 1.

Uji H siao-G ranger Causality Beberapa Besaran M oneter dengan Inflasi

\begin{tabular}{|c|c|c|c|c|}
\hline Causality & Lag & AIC & AIC* & Keterangan \\
\hline $\mathrm{M} 1 \rightarrow \mathrm{MO}$ & $(1,1)$ & 18.09 & 18.08 & HO ditolak \\
\hline $\mathrm{MO} \rightarrow \mathrm{M} 1$ & $(1,1)$ & 21.827 & 21.81 & HO ditolak \\
\hline $\mathrm{M} 2 \mathrm{Rp} \rightarrow \mathrm{M} 0$ & $(2,1)$ & 18.064 & 18.08 & HO diterima \\
\hline $\mathrm{MO} \rightarrow \mathrm{M} 2 \mathrm{Rp}$ & $(1,2)$ & 19.7187 & 19.75 & HO diterima \\
\hline $\mathrm{MO} \rightarrow \mathrm{UDL}$ & $(1,3)$ & 2.674 & 3.061 & HO diterima \\
\hline CPIUDL $\rightarrow$ MO & $(3,1)$ & 18.1 & 18.08 & HO ditolak \\
\hline M $1 \rightarrow$ UDL & $(1,3)$ & 2.09 & 3.061 & HO diterima \\
\hline CPIUDL $\rightarrow$ M 1 & $(3,1)$ & 21.845 & 21.81 & HO ditolak \\
\hline $\mathrm{M} 2 \mathrm{Rp} \rightarrow \mathrm{UDL}$ & $(2,3)$ & 2.849 & 3.061 & HO diterima \\
\hline CPIUDL $\rightarrow$ M 2Rp & $(3,2)$ & 19.616 & 19.75 & HO diterima \\
\hline
\end{tabular}

*AIC Optimal masing-masing variabel

Dari hasil uji tersebut terlihat bahwa pengaruh M0 terhadap M2 Rupiah (M2Rp) bersifat bidirectional causality, sementara itu tidak terdapat hubungan antara M 0 dan M 1 . Selanjutnya terlihat bahwa M0, M 1 dan M 2Rp berpengaruh secara searah (unidirectional causality) terhadap inflasi underlying. Dengan demikian, hasil tersebut tidak seluruhnya mendukung hipotesistentang mekanismetransmisi dari kebijakan moneter (quantity approach) yang telah dikemukakan sebelum ini, yaitu bahwa perubahan M 0 (operational target) akan mempengaruhi M 1/ M2Rp yang kemudian akan berpengaruh terhadap inflasi. Kenyataan bahwa hubungan antara M 0 dengan M 1 atau M 2Rp yang tidak sesuai harapan, dibarengi oleh hubungan yang cukup kuat antara M O langsung kepada inflasi underlying, sehingga fungsi M1 atau M2sebagai intermediary target menjadi berkurang.

Berkaitan dengan adanya 2 jenis besaran moneter, yaitu M 1 dan M2Rp, yang dianggap sebagai intermediary target, perlu dilakukan pengujian untuk melihat jenis jumlah uang beredar yang mana yang lebi $h$ berpengaruh terhadap laju inflasi . Hasil pengujian variance decomposition menunjukkan bahwa M1 mempunyai pengaruh yang lebih besar terhadap inflasi underlying dibandingkan dengan M2Rp (lihat Tabel 2). Penjelasan yang dapat diberikan untuk temuan ini adalah karena permintaan M 1 merupakan cerminan dari effective purchasing power, sehingga peningkatan permintaan $M 1$ berarti peningkatan real spending yang akan menimbulkan tekanan inflasi dari sisi permintaan (demand pull inlation). 
Tabel 2.

Perbandingan V ariance D ecomposition Uang Kartal, M0, M 1 dan M2Rupiah Terhadap Underlying Inflation

\begin{tabular}{|c|r|r|r|r|}
\hline Period & CURR & M 0 & M 1 & M 2R p \\
\hline 1 & 4.79 & 0.76 & 1.03 & 0.56 \\
2 & 40.83 & 25.14 & 54.57 & 13.01 \\
3 & 45.00 & 28.82 & 61.54 & 21.67 \\
4 & 46.83 & 30.42 & 63.52 & 24.96 \\
5 & 47.31 & 30.91 & 64.19 & 26.11 \\
6 & 47.50 & 31.11 & 64.44 & 26.57 \\
7 & 47.60 & 31.23 & 64.56 & 26.80 \\
8 & 47.69 & 31.33 & 64.62 & 26.93 \\
9 & 47.78 & 31.43 & 64.65 & 27.01 \\
10 & 47.89 & 31.53 & 64.68 & 27.07 \\
\hline
\end{tabular}

Dengan kerangka hipotesismekanismetransmisi melalui agregat moneter seperti telah dijelaskan pada awal bab ini, pengujian selanjutnya akan mengukur policy lag yang dibutuhkan. Yaitu berapa lama kebijakan moneter melalui perubahan base money (M0) akan berpengaruh terhadap laju inflasi underlying. Untuk maksud tersebut telah dilakukan uji impulseresponse (V ector A utoregression, V A R) dengan menggunakan data kuartalan dari tahun 1990 - 1999 yang hasilnya seperti terlihat pada grafik 1.

Hasil uji tersebut menunjukkan bahwa mekanismetransmisi quantity approach yang direpresentasikan melalui M0sebagai operational target mempunyai pengaruh positif (initial shock) terhadap M1 sebagai intermediary target dengan policy lag 0-1 kuartal. Sementara, perubahan M 1 membutuhkan lag selama 5 kuartal untuk mempengaruhi inflasi underlying. Dengan demikian lag secara keseluruhan antara operational target dengan ultimate target (underlying inflation) adalah sekitar 5-6 kuartal ${ }^{15}$ (lihat Grafik 1).

\section{G rafik 1}

Impulse Transmisi Kebijakan M oneter D engan Q uantity A pproach

Response to One S.D. Innovations \pm 2 S.E.
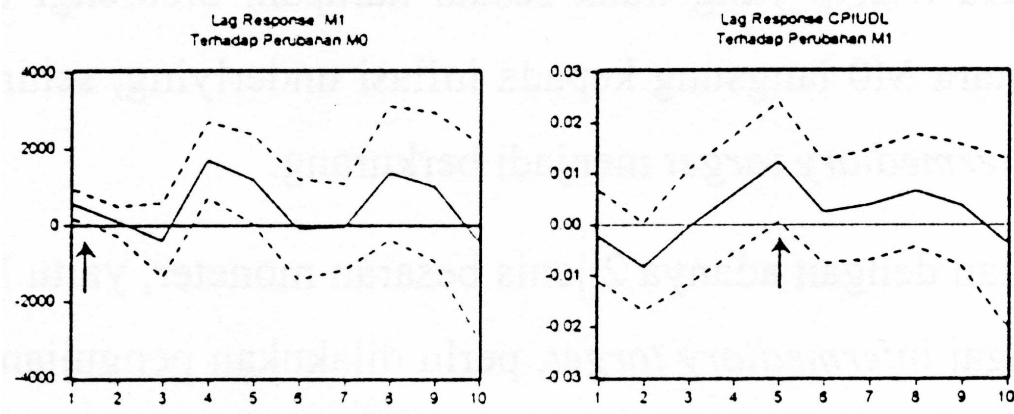

15 Sebagai perbandingan, di negara Korea lag antara peningkatan uang beredar dengan inflasi sekitar 2 tahun 
Meski tidak persis seperti apa yang diperkirakan semula, masih berjalannyatransmisi kebijakan moneter dalam kerangka quantity approach seperti yang telah diuraikan di atas menunjukkan bahwa kerangka kebijakan moneter yang selama ini ditempuh oleh Bank Indonesia cukup efektif mempengaruhi inflasi.

Meskipun demikian, dengan semakin berkembangnya perekonomian nasional khususnya pasar keuangan, pendekatan ini semakin sulituntuk diterapkan. Perilaku velocity dan money multiplier - yang merupakan hal yang penting dalam quantity approach, menjadi semakin tidak stabil. Ketidakstabilan perilaku incomevel ocity antara lain terutama berkaitan dengan deregulasi sektor keuangan yang diikuti dengan financial innovation yang telah menyebabkan adanya perubahan behaviour masyarakat dalam melakukan transaksi keuangan. Besarnya for eign capital inflow pasca deregulasi ekonomi juga telah mengakibatkan proses financial deepening berubah dengan cepat sehingga mempengaruhi pertumbuhan dari besaran-besaran moneter yang pada gilirannya menyebabkan perilaku money multiplier semakin tidak stabil (Sarwono, 1997 dan Solikin, 1998). Dari sisi kebijakan, hubungan yang tidak stabil tersebut menyebabkan sulitnya menentukan target operasional yang optimal.

Perubahan perilaku money multiplier tersebut bahkan telah menyebabkan hubungan jangka panjang antara M 0 dengan M 1 dan M 2 menjadi tidak stabil seperti yang terlihat dari hasil uji kointegrasi berikut ini. Hasil ini sejalan dengan pengujian causality seperti yang telah dibahas sebelumnya.

Tabel 3.

Uji Kointegrasi Johansen's M aximum likelihood Terhadap M 0, M 1 dan M 2R upiah

\begin{tabular}{|c|c|c|c|}
\hline Ho & $r=0$ & $\begin{aligned} r<1 \\
r=2\end{aligned}$ & \multirow{3}{*}{$\begin{array}{c}\text { Cointe- } \\
\text { gration } \\
\%\end{array}$} \\
\hline H1 & $r=1$ & $r=2$ & \\
\hline & \multicolumn{2}{|c|}{ Likelihood Ratio(LR) } & \\
\hline $69.6-99.7$ & & & \\
\hline $\log M 0$ dan $\log M 1$ & 12.230 & 0.591 & - \\
\hline $\log$ dan $\log M 2 R p$ & 8.962 & 2.381 & - \\
\hline 69.6-88.12 & & & \\
\hline $\log M 0$ dan $\log M 1$ & $28.145 * *$ & $4.515^{*}$ & 2 \\
\hline $\log$ dan log M2Rp & $21.503^{* *}$ & 1.037 & 1 \\
\hline 89.1-99.7 & & & \\
\hline $\log$ M0dan $\log M 1$ & 12.120 & 0.003 & - \\
\hline $\log M 0$ dan $\log M 2 R p$ & 13.438 & 1.391 & - \\
\hline Critical values: & 20.04 & 6.65 & - \\
\hline $5 \%$ & 15.41 & 3.76 & - \\
\hline
\end{tabular}

*(**) denotes rejection of the hypothesis at $5 \%(1 \%)$ significancelevel 
Dari tabel 3 di atas terlihat bahwa variabel $\mathrm{M} 1$ dan $\mathrm{M} 2$ rupiah hanya mempunyai hubungan jangka panjang (co-integrated) dengan M0 sampai dengan periode tahun 1988. Namun sejalan dengan pesatnya liberalisasi sektor keuangan setelah periode tersebut, hubungan tersebut melemah. Hasil uji kointegrasi dengan menggunakan Engle Granger menunjukkan fenomena yang sama. $\mathrm{Hal}$ ini membuktikan bahwa hubungan jangka panjang antara M0 dengan $\mathrm{M} 1$ dan $\mathrm{M} 2$ rupiah tidak stabil sehingga akan mengurangi efektifitas kebijakan moneter yang menggunakan quantity approach.

Hal lain yang dapat mengurangi efektifitas pengendalian moneter yang berbasis quantity approach adalah berkaitan dengan sulitnya pasar untuk menangkap signal arah kebijakan moneter yang akan dilakukan oleh Bank Indonesia. Dengan mengasumsikan bahwa perilaku peserta pasar (bank-bank) tercermin pada kondisi likuiditasnya yang terefleksikan pada harga di PUAB (Suku Bunga), maka respon dari pasar terhadap setiap signal kebijakan moneter akan tergambar pada perubahan suku bunga PUAB. Hasil uji variance decomposition atas suku bungaJIBO R O/N menunjukkan bahwa peranan perubahan base money - sebagai operational target - dalam pembentukan ekspektasi peserta pasar (perbankan) relatif kecil, yaitu sekitar 5\% (lihat Tabel 4). Sejalan dengan itu, hasil uji granger causal ity menerima hipotesa $(\mathrm{H} 0)$ bahwa perubahan base money tidak mempengaruhi suku bungaJIBOR O/ N.

Tabel 4.

Uji V ariance D ecomposition Suku BungaJIBOR O/N

\begin{tabular}{|c|c|c|r|r|}
\hline \multicolumn{5}{|c|}{ Varian D ecomposition of JIBOR } \\
\hline Period & S.E & Base M oney & \multicolumn{2}{|c|}{ Suku Bunga } \\
\cline { 4 - 5 } & & & $\begin{array}{c}\text { Intervensi } \\
\text { Rp }\end{array}$ & JIBOR O/N \\
\hline 1 & & & 3.51 & 94.29 \\
5 & 0.39 & 2.20 & 24.81 & 73.52 \\
10 & 1.09 & 1.66 & 57.62 & 41.03 \\
15 & 1.38 & 2.41 & 72.24 & 25.34 \\
20 & 1.64 & 3.31 & 78.54 & 18.15 \\
25 & 1.85 & 3.88 & 81.82 & 14.30 \\
30 & 2.02 & 4.26 & 83.79 & 11.95 \\
\hline
\end{tabular}

Ordering: Base Money INTJIBOR

Pairwise Granger Causality Testsa

Date: 10/ 25/ 99 Time: 14:10

Sample: 1130

Lags: 5

\begin{tabular}{|lrrl|}
\hline Null hypothesis: & Obs & F-Statistic & Probability \\
BM does not Granger Cause Suku BungaJIBO 118 & 1.25663 & 0.28814 \\
Suku BungaJIBOR does not Granger CauseBM & 1.26741 & 0.28339 \\
& & & \\
\hline
\end{tabular}




\section{Jalur Suku Bunga (Pasive Money Approach)}

Sementara itu, dalam pendekatan harga (priceapproach) kebijakan moneter dijal ankan dengan menggunakan suku bunga jangka pendek sebagai operational target yang kemudian diperkirakan akan mempengaruhi variabel-variabel harga di pasar keuangan, sektor riil dan pada akhirnya pada laju inflasi. Berbeda dengan pendekatan ini, dimana suku bunga secara aktif digunakan sebagai instrumen, dalam pandangan quantity approach suku bunga hanya dianggap sebagai resultante dari pencapaian target besaran moneter.

Berkaitan dengan penggunaan suku bunga sebagai instrumen moneter, sampai dengan saat ini Bank Indonesia dalam operasional pengelolaan moneternya mempunyai dua jenis suku bunga, yaitu SBI dan Intervensi Rupiah. Dengan adanya dua jenis suku bunga tersebut, pertama kali perlu dikaji suku bunga mana yang mempunyai pengaruh paling kuat dalam proses transmisi kebijakan moneter, yaitu dengan melihat pengaruhnya terhadap pembentukan suku bunga PUAB. Secara implisit hal ini juga menggambarkan kekuatan respon pasar atas arah kebijakan moneter yang ditempuh Bank Indonesia.

Dengan menggunakan data harian, uji varian decomposition menunjukkan bahwa suku bunga intervensi rupiah $(\mathrm{O} / \mathrm{N})$ mempunyai pengaruh yang lebih kuat (75\%) dibanding dengan suku bunga SBI Satu Bulan (17\%) terhadap pergerakan suku bunga PUAB, yang dalam hal ini diwakili oleh suku bunga JIBOR O/ N (lihat Tabel 5). Meskipun demikian, hasil ini harus diterima dengan catatan bahwa data SBI tidak berubah secara harian, melainkan secara mingguna sesuai dengan tanggal lelang. Kuatnya pengaruh intervensi rupiah terhadap PUAB mencerminkan bahwa fungsi finetuning, yaitu untuk menstabilkan fluktuasi suku bunga, dari penggunaan intervensi rupiah dalam manajemen moneter harian telah bekerja dengan baik.

Tabel 5.

Uji D ekomposisi Suku BungaJIBOR

\begin{tabular}{|c|r|r|r|r|}
\hline \multicolumn{5}{|c|}{ Variance decomposition of JIBOR: } \\
\hline Period & \multicolumn{1}{|c|}{ S.E. } & \multicolumn{1}{c|}{ SBI } & \multicolumn{1}{c|}{ INT } & JIBOR \\
\hline 1 & 0.35 & 1.07 & 1.07 & 97.86 \\
5 & 0.67 & 28.64 & 14.98 & 56.37 \\
10 & 1.06 & 23.59 & 5337 & 23.04 \\
15 & 1.39 & 19.98 & 66.22 & 13.80 \\
20 & 1.66 & 18.18 & 71.64 & 10.18 \\
25 & 1.87 & 17.16 & 74.51 & 8.33 \\
30 & 2.05 & 16.52 & 76.26 & 7.22 \\
\hline
\end{tabular}

Ordering: SBI INTJIBOR

Permasalahan yang muncul berkaitan dengan akan digunakannya intervensi rupiah dalam pengujian mekanismetransmisi melalui jalur suku bunga adalah adanya keterbatasan 
data statistik intervensi rupiah, karena sistem ini baru dimulai pada bulan Juli 1998, sementara pengujian mekanisme transmisi kebijakan moneter sebagai suatu simplifikasi dari perekonomian membutuhkan runtun data yang cukup panjang untuk menjaga konsistensi.

Untuk mengatasi masalah ketersediaan data tersebut, maka digunakan suku bunga SBI 1 bulan sebagai proxy suku bunga intervensi rupiah. Dasar pertimbangan yang pertama adalah suku bunga SBI 1 bulan berhubungan erat dengan suku bunga intervensi rupiah (uji korelasi memberikan hasil 0,9), sedangkan alasan kedua berkaitan dengan besarnya peranan SBI 1 bulan dalam pengendalian moneter di Indonesia ${ }^{16}$. Selanjutnya dengan menggunakan suku bunga SBI 1 bulan sebagai policy instrument akan dikaji proses transmisi kebijakan moneter dalam mempengaruhi inflasi (underlying) melalui jalur pasar keuangan (suku bunga deposito 1 bulan), nilai tukar, permintaan agregat dan output gap (lihat tabel 6).

Tabel 6.

Uji Hsiao-G ranger Causality Suku Bunga, $\mathbf{N}$ ilai Tukar, $\mathbf{O}$ utput $\mathrm{G}$ ap dan Inflasi Undelrying

\begin{tabular}{|l|r|r|r|r|}
\hline \multicolumn{1}{|c|}{ Causality } & \multicolumn{1}{c|}{ Lag } & \multicolumn{1}{c|}{ AIC } & \multicolumn{1}{c|}{ AIC* } & Keterangan \\
\hline SBI $\rightarrow$ Dep 1 Bulan & $(5,2)$ & 5.7575 & 6.026 & HO diterima \\
Dep 1 Bulan ®SBI & $(2,5)$ & 5.8444 & 6.409 & HO diterima \\
& $(5,3)$ & 6.982 & 7.243 & HO diterima \\
SBI $\rightarrow$ REER & $(3,5)$ & 5.238 & 6.409 & HO diterima \\
REER $\rightarrow$ SBI & $(2,3)$ & 7.208 & 7.243 & HO diterima \\
DEP 1 Bulan $\rightarrow$ REER & $(3,2)$ & 4.996 & 6.026 & HO diterima \\
REER $\rightarrow$ Dep 1Bulan & $(2,3)$ & 19.249 & 19.288 & HO diterima \\
& $(3,2)$ & 5.474 & 6.026 & HO diterima \\
DEP 1 Bulan $\rightarrow$ Output Gap & $(3,3)$ & 18.762 & 19.288 & HO diterima \\
Output Gap $\rightarrow$ Dep 1Bulan & $(3,3)$ & 7.255 & 7.243 & HO ditolak \\
& $(3,1)$ & 6.067 & 7.2559 & HO diterima \\
REER $\rightarrow$ OutputGap & $(1,3)$ & 7.114 & 7.243 & HO diterima \\
OutputGap $\rightarrow$ REER & $(3,1)$ & 7.004 & 7.2559 & HO diterima \\
& $(1,3)$ & 19.299 & 19.288 & HO ditolak \\
REER $\rightarrow$ Inflasi Underlying & &
\end{tabular}

*AIC Optimal masing-masing variabel

16 lihat juga Warjiyo dan Zulverdi 'Penggunaan Suku Bunga Sebagai Sasaran Operasional Kebijakan Moneter di Indonesia 
Tahap pertama proses transmisi kebijakan moneter dalam price approach adalah mendeskripsikan hubungan antara policy instrument (suku bunga), suku bunga pasar uang, dan longer term interest rate. Hasil uji empiris menunjukan bahwa perubahan policy instrument akan secara cepat diikuti oleh suku bunga pasar uang dalam arah yang sama. Kemudian, perubahan suku bunga pasar uang akan diikuti oleh penyesuaian suku bunga simpanan dan pinjaman, meskipun dengan intensitas yang lebih rendah. Respon dari longer term interest rate terhadap perubahan interest rate policy tersebut disamping dipengaruhi oleh current interest rate juga akan tergantung dari persepsi pasar tentang future path dari suku bunga.

Hasil uji kausalitas dengan menggunakan data bulanan 1990-1999 menunjukkan bahwa terdapat hubungan satu arah (unilateral causality) antara suku bunga SBI (monetary policy instrument) dengan suku bunga PUAB overnight dan longer term interest rate.

A danya hubungan tersebut menunjukkan bahwa suku bungajangka pendek (PUAB) dapat dipengaruhi secara langsung oleh Bank Indonesia (controlable). Artinya, signal arah kebijakan moneter dapat di"tangkap" dan direspon oleh pasar secara efektif. Dalam pada itu, respon suku bunga yang berjangka waktu lebih panjang - yaitu suku bunga deposito 1 dan 3 bulan - terhadap perubahan SBI juga menunjukkan hal yang sama. Uji impulserespons suku bunga deposito terhadap perubahan suku bunga SBI memperlihatkan hubungan tersebut dengan lag 1 - 4 bulan untuk deposito 1 bulan dan 2 - 5 bulan untuk deposito 3 bulan.

Tabel 7.

H asil Uji H siao- G ranger Causality Suku Bunga

\begin{tabular}{|l|r|r|r|r|}
\hline \multicolumn{1}{|c|}{ Causality } & \multicolumn{1}{c|}{ Lag } & \multicolumn{1}{c|}{ AIC } & \multicolumn{1}{c|}{ AIC* } & Keterangan \\
\hline $\mathrm{SBI} \rightarrow$ O/ N & $(1,1)$ & 5.425 & 5.49 & HO Diterima \\
O/ N $\rightarrow$ SBI & $(1,1)$ & 4.824 & 3.324 & HO ditolak \\
SBI $\rightarrow$ DEP 1 Bulan & $(1,2)$ & 4.607 & 4.73 & HO Diterima \\
DEP 1 Bulan $\rightarrow$ SBI & $(2,1)$ & 4.98 & 3.388 & HO ditolak \\
& $(1,1)$ & 3.349 & 3.58 & HO Diterima \\
SBI $\rightarrow$ DEP 3 Bulan & $(1,1)$ & 4.938 & 3.388 & HO ditolak \\
DEP 3 Bulan $\rightarrow$ SBI & & & & \\
& $(1,2)$ & 4.59 & 4.73 & HO Diterima \\
O/ N $\rightarrow$ Dep 1 Bulan & $(2,1)$ & 5.53 & 5.49 & HO ditolak \\
DEP 1 Bulan $\rightarrow$ O/ N & $(1,1)$ & 3.47 & 3.58 & HO diterima \\
& $(1,1)$ & 5.44 & 5.49 & HO diterima \\
O/ N $\rightarrow$ Dep 3Bulan & & &
\end{tabular}

*Causality Optimal masing-masing variabel 


\section{G rafik 2.}

Uji Impulse Response Suku Bunga

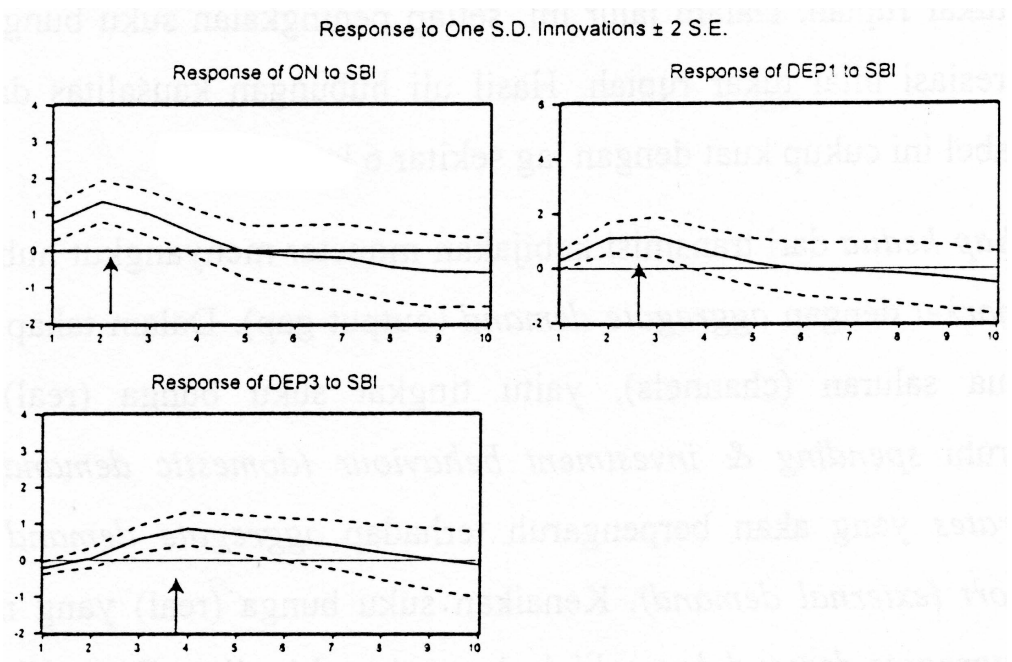

Hasil pengujian tersebut menyimpulkan hubungan yang erat antara instrumen kebijakan moneter (SBI) dengan suku bungaPUAB dan suku bungasimpanan yang berjangka waktu lebih panjang. Dalam hal ini, Bank Indonesia dapat secara efektif mempengaruhi perilaku pasar melalui suku bunga. Kesimpulan tersebut didukung pula oleh hasil pengujian Iain, yaitu bahwa antara suku bunga SBI, PUAB overnight, Deposito 1 bulan dan 3 bulan

Tabel 8.

Uji Kointegrasi Suku Bunga SBI, D eposito 1 dan 3 Bulan

\begin{tabular}{|c|c|c|c|}
\hline Ho & $r=0$ & $r<1$ & \multirow{3}{*}{$\begin{array}{l}\text { Cointe- } \\
\text { gration } \\
(1 \%)\end{array}$} \\
\hline H1 & $r=1$ & $r=2$ & \\
\hline & \multicolumn{2}{|c|}{ Likelihood Ratio (LR) } & \\
\hline $\begin{array}{l}\text { 1990.1-1999.7 } \\
\text { Suku Bunga O/ N dan SBI } \\
\text { Suku Bunga Dep } 1 \text { dan SB } \\
\text { Suku Bunga Dep 3 dan SBI }\end{array}$ & $\begin{array}{l}23.208^{* *} \\
32.097^{* *} \\
33.233^{* *}\end{array}$ & $\begin{array}{r}3.868^{*} \\
3.308 \\
5.698^{*}\end{array}$ & $\begin{array}{l}2 \\
1 \\
2\end{array}$ \\
\hline $\begin{array}{c}\text { 1990.1-1997.6 } \\
\text { Suku Bunga O/ N dan SBI } \\
\text { Suku Bunga Dep } 1 \text { dan SBI }\end{array}$ & $\begin{array}{l}17.468^{*} \\
19.912^{*}\end{array}$ & $\begin{array}{l}1.208 \\
1.580\end{array}$ & $\begin{array}{l}1 \\
1\end{array}$ \\
\hline $\begin{array}{c}\text { Suku Bunga Dep } 3 \text { dan SBI } \\
\text { 1997.7 - 1999.7 }\end{array}$ & $31.845^{* *}$ & 1.773 & 1 \\
\hline $\begin{array}{l}\text { Suku bunga O/ N dan SBI } \\
\text { Suku bunga Dep } 1 \text { dan SBI } \\
\text { Suku bunga Dep } 3 \text { dan SBI }\end{array}$ & $\begin{array}{r}24.252^{* *} \\
15.889^{* *} \\
17.144^{*}\end{array}$ & $\begin{array}{r}3.302 \\
3.916^{*} \\
4.710^{*}\end{array}$ & $\begin{array}{l}1 \\
2 \\
2\end{array}$ \\
\hline 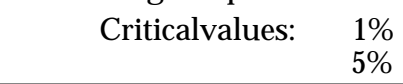 & $\begin{array}{l}20.04 \\
15.41\end{array}$ & $\begin{array}{l}6.65 \\
3.76\end{array}$ & \\
\hline
\end{tabular}

$*(* *)$ denotes rejection of the hypothesis at 5\%(1\%) significance level $(+)$ denotes 1 cointegrated at $5 \%$ significance level 
mempunyai hubungan jangka panjang (co-integrated) yang stabil (Tabel 8). Secara keseluruhan, pengaruh dari policy factor terhadap suku bunga berlangsung cepat/ seketika (initial shock) dengan lag maksimal 2 kuartal.

Sementara itu dari sisi eksternal, perubahan suku bunga SBI juga direspon oleh nilai tukar rupiah. Dalam jalur ini, setiap peningkatan suku bunga SBI diikuti dengan apresiasi nilai tukar rupiah. Hasil uji hubungan kausalitas dan VAR dari kedua variabel ini cukup kuat dengan lag sekitar 6 kuartal.

Tahap kedua dari transmisi kebijakan moneter menyangkuthubungan antarafinancial market dengan aggregatedemand (output gap). Dalam tahap ini, minimal terdapat dua saluran (channels), yaitu tingkat suku bunga (real) yang akan mempengaruhi spending \& investment behaviour (domestic demand), sertareal exchangerates yang akan berpengaruh terhadap aggregate demand melalui net export import (external demand). Kenaikan suku bunga (real) yang menyebabkan turunnyaaggregatedemand dapat dijelaskan sebagai berikut. Dari sisi individu, hal ini terutama diakibatkan oleh berubahnya disposable income individual yang mengakibatkan dana yang tersedia untuk belanja barang $\&$ jasa menurun. Disamping itu, perubahan melalui wealth effect antara lain menyebabkan menurunnyakemampuan individu untuk menyediakan jaminan kredit sehingga permintaan kredit menurun. Dari sisi perusahaan, dalam kondisi relatif terbatasnya sumber dana di luar perbankan dan besarnya peranan kredit perbankan dalamstruktur pendanaan perusahaan, peningkatan suku bunga (pinjaman) juga akan menyebabkan meningkatnya biaya modal perusahaan tersebut yang berakibat pada menurunnya pendapatan dan kemampuan untuk melakukan ekspansi usaha (investasi).

Berkaitan dengan pengaruh nilai tukar terhadap aggregate demand, penelitian yang dilakukan Waluyo dkk (1998) menyimpulkan bahwa perubahan (depresiasi) nilai tukar riil akan meningkatkan kinerja ekspor (non migas) demikian pula sebaliknya. Penelitian yang sama menyimpulkan bahwa elastisitas hubungan REER dengan ekspor semakin membesar sejalan dengan semakin besarnya peran ekspor manufaktur. Respon perubahan ekspor atas perubahan REER membutuhkan waktu sekitar 2 samai dengan 6 triwulan. Peningkatan ekspor ini padagilirannyaakan meningkatkan total demand sehingga outputgap meningkat.

Dari pembahasan jalur-jalur transmisi di atas, time lag terpendek dari perubahan monetary policy (suku bunga SBI) terhadap output gap adalah melalui jalur suku bunga deposito, yaitu dengan lag sekitar 4 - 5 kuartal, seperti yang ditunjukkan oleh hasil uji impulse response berikut. 
Grafik 3.

Uji Impulse ResponseT ransmisi Kebijakan M oneter Price A pproach
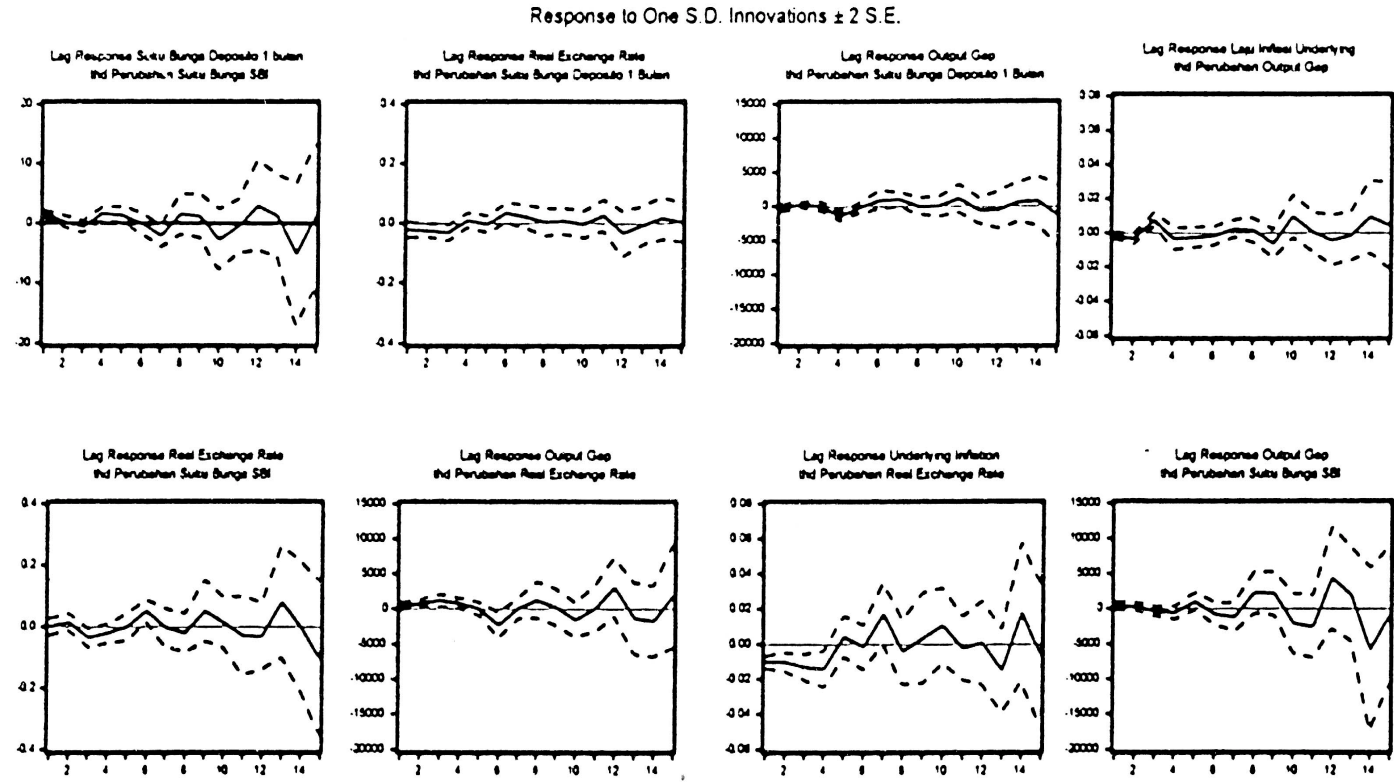

Tahap ketiga menggambarkan proses transmisi dari output gap keinflasi underlying. Meningkatnya output gap yang berarti total permintaan relatif lebih besar daripada output potensial mencerminkan adanya excess demand yang akan menimbulkan tekanan pada inflasi underlying dengan time lag sekitar 3 triwulan. Dari sisi eksternal, passthrough perubahan nilai tukar terhadap inflasi berjalan melalui mekanisme imported inflation dimana depresiasi nilai tukar rupiah akan menyebabkan barang-barang import -- notabenemempunyai peran yang besar dalam struktur industri dan konsumsi agregat Indonesia - menjadi relatif mahal. Seperti variabel-variabel yang lain, pengaruh perubahan nilai tukar terhadap harga barang juga mempunyai timelag yang disebabkan oleh perilaku produsen dalam menetapkan harga barang, dimana didalamnya terdapat bahan impor. Dalam hal ini, produsen tidak secara langsung melakukan re pricing terhadap setiap perubahan nilai tukar, melainkan tergantung dari sifat perubahan nilai tukar itu (sementara atau permanen). Passthrough dari nilai tukar ke inflasi (underlying) diperkirakan berjalan secara gradual hingga mencapai maksimal setelah 4 triwulan kedepan.

Dari tiga tahap pengujian mekanisme transmisi kebijakan moneter di atas, skema berikut menyimpulka urutan respon variabel-variabel atas perubahan policy instrument, beserta dengan policy lag untuk setiap respon. 
G rafik 4.

Flowchart Lag Transmisi Kebijakan M oneter

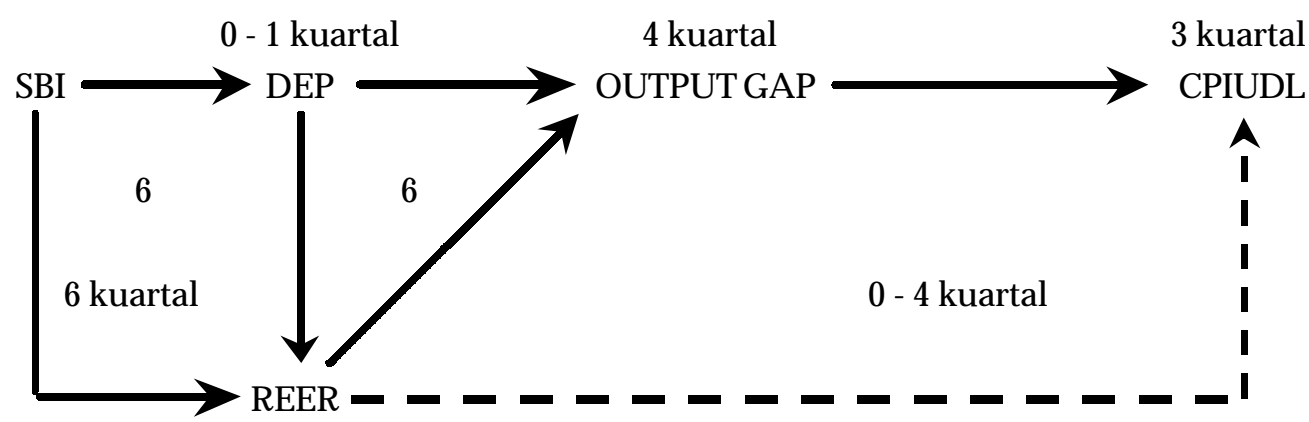

Time lag dari mulai perubahan suku bunga SBI ke suku bunga deposito maupun REER, dari suku bunga deposito dan REER ke output gap, dan dari output gap ke inflasi menunjukankan bahwa monetary policy (suku bunga) membutuhkan waktu yang cukup lama untuk mempengaruhi inflasi (underlying) seperti yang ditunjukkan oleh grafik 4. Secara singkat, diperlukan sekitar 8 kuartal ( 2 tahun) bagi policy instrumnet (suku bunga) untuk dapat mempengaruhi inflasi. Secara implisithal ini berarti bahwa kebijakan moneter dalam mempengaruhi inflasi harus bersifat pre-emptive.

Mekanisme pengaruh kebijakan moneter terhadap inflasi underlying yang bersifat indirect tersebut akan dapat berjal an secara efektif jika variabel-variabel yang menjadi channel bagi transmisi kebijakan tersebut mempunyai hubungan yang erat. Berkaitan dengan hal tersebut, telah dilakukan uji kointegrasi - seperti yang telah dilakukan dalam pengujian mekanisme transmisi pada quantity approach - untuk melihat hubungan jangka panjang antar variabel yang menjadi channel jalur transmisi di mana hasilnya dapat dilihat pada tabel 9.

Dari hasil uji tersebut terlihat bahwa dalam kurun waktu 9 tahun terakhir, hubungan jangka panjang (cointegration) antar variabel-variabel transmisi kebijakan moneter yang berbasis pada priceapproach, yakni suku bunga deposito, REER, Output Gap dan U nderlying Inflation semakin kuat. Hal ini berarti kebijakan moneter dengan berbasis suku bunga akan lebih efektif mengendalikan laju inflasi underlying, relatif terhadap mekanisme transmisi yang berbasis pada agregat moneter.

\section{Poole's Analysis: O ptimal Choice of Monetary Policy}

Guna melengkapi kajian tentang pilihan kebijakan moneter, seperti yang telah dibahas di atas, berikut dicoba untuk menerapkan pendekatan 0 ptimal Choice of $\mathrm{M}$ onetary Policy yang dikembangkan oleh Poole (1970). Pendekatan ini pada prinsipnya mencoba untuk memberikan landasan bagi pemilihan jenis kebijakan tertentu dengan dasar minimisasi expected 
Tabel 9.

Uji Kointegrasi Johansen's M aximum Likelihood Terhadap D eposito, O uput G ap, REER dan Underlying Inflation

\begin{tabular}{|c|c|c|c|}
\hline Ho & $\mathbf{r}=\mathbf{0}$ & $\mathbf{r}<\mathbf{1}$ & Cointe \\
H 1 & $\mathbf{r}=\mathbf{1}$ & $\mathbf{r = 2}$ & \multirow{2}{*}{ gration } \\
1990.3-1997.2 & \multicolumn{2}{|c|}{ Likelihood Ratio (LR) } & $(1 \%)$ \\
\cline { 2 - 3 } SBI-Deposito & $35.446^{* *}$ & 1.407 & \\
Deposito-Output gap & 19.4218 & $7.979^{* *}$ & 2 \\
REER - Output Gap & $23.164^{* *}$ & 0.028 & 1 \\
REER Underlying Inf & $17.190^{*}$ & 1.770 & 1 \\
Output gap-Underlying & $21.353^{* *}$ & 1.430 & 1 \\
& & & \\
1990.3 - 1999.1 & & & \\
SBI - Deposito & $44.347^{* *}$ & $10.861^{* *}$ & 2 \\
Deposito-output gap & $24.585^{* *}$ & $8.924^{* *}$ & 2 \\
REER- output gap & $17.073^{*}$ & $6.823^{*}$ & 2 \\
REER-underlying Inf & $38.787^{* *}$ & $11.446^{* *}$ & 2 \\
Output gap-underlying inf & $21.561^{* *}$ & $8.733^{* *}$ & 2 \\
\hline Critical values: & $1 \%$ & 20.04 & 6.65 \\
& $5 \%$ & 15.41 & 3.76 \\
\hline
\end{tabular}

$*(* *)$ denotes rejection of the hypothesis at $5 \%(1 \%)$ significance level

loss dari output, sehingga dari sisi praktis dengan membandingkan expected loss dari penggunaan jumlah uang beredar sebagai instrumen dengan expected loss dari penggunaan suku bunga sebagai instrumen dengan kerangka pendekatan IS-LM (latar belakang teoritis dapat dilihat di bab 2) pilihan instrumen kebijakan akan diberikan kepada instrumen yang menghasilkan expected loss yang relatif lebih kecil.

Seperti yang telah dikemukakan dalam kajian teoritis, tahap pertama dalam pendekatan Pooleadalah melakukan estimasi persamaan struktural dari IS dan LM, dimana hasilnya adalah sebagai berikut

$$
\begin{aligned}
& \log _{t}=13.20-7.48 R_{t} \\
& \text { (295) } \quad(-11.39) \quad(\mathrm{se}=0.09) \\
& \log M 2 R p_{t}=-0.32+0.58 \log Y_{t}-12.6 R_{t} \\
& (-0.08) \quad(1.95) \quad(-12.6) \quad(\mathrm{se}=0.16) \text { : } \\
& \mathrm{Y}=\text { PDB Riil Tahunan } \\
& \mathrm{R}=\text { Suku Bunga SBI Satu Bulan Riil } \\
& \text { M2Rpr = M2Rupiah Riil. }
\end{aligned}
$$


Hasil regresi tersebut memberikan koefisien dengan sign yang sesuai dengan hipotesa, dimana suku bunga SBI berpengaruh negatif terhadap PDB \& permintaan uang riil (R eal Balance) sementara pendapatan (PDB riil) mempunyai pengaruh positif terhadap permintaan uang riil.

Tahap kedua adalah menghitung expected loss dari masing-masing alternatif instrumen kebijakan moneter yakni dengan mensubstitusikan persamaan struktural tersebut di atas ke dalam quadratic loss function $\left(\mathrm{L}=\mathrm{E}\left[\left(\mathrm{Y}-\mathrm{Y}_{\mathrm{f}}\right)^{2}\right]\right.$ ) yang kemudian menghasilkan expected loss dari penggunaan suku bunga dan jumlah uang sebagai instrumen masing-masing secara berurutan $L_{r}=0.0079$ dan $L_{M}=0.0094$. 0 ptimal monetary policy ditentukan dengan melihat minimally expected loss dari masing-masing kebijakan sehingga jika rasio $L_{M} / L_{r}$ lebih kecil dari 1 maka kebijakan money stock bersifat lebih superior dibandingkan dengan kebijakan suku bunga. Hasil perhitungan rasio $L_{M} / L_{r}$ memberikan angka 1.19 - lebih besar dari $1-$ yang berarti expected loss dari penggunaan suku bunga sebagai instrumen kebijakan moneter $\left(\mathrm{L}_{\mathrm{r}}\right)$ relatif lebih kecil sehingga dapat diambil kesimpulan bahwa kebijakan moneter yang berbasis pada suku bunga lebih superior dibandingkan dengan kebijakan moneter yang berbasis pada money stock (quantity approach).

Satu hal yang perlu diperhatikan disini adalah masalah superioritaskebijakan moneter yang berbasis pada suku bunga dibanding kebijakan moneter yang berbasis pada money stock - yang menyiratkan bahwa sumber shock yang terjadi di Indonesia lebih berasal dari shock pada pasar uang (lihat tinjauan teori) - berbeda dengan hasil kajian tentang Pemilihan Sistem Nilai Tukar di Indonesia (DKM, 1999) yang telah dilakukan sebelumnya, dimana dengan menggunakan $\mathrm{M}$ undell-Flemming-D onrbush model - disimpulkan bahwa sumber utama shock di Indonesia berasal dari pasar barang. Perbedaan hasil ini dimungkinkan mengingat bahwa kajian Poole's analysis berorientasi pada sisi permintaan dari sebuah perekonomian tertutup, sementara M undell-Flemming model lebih berorientasi pada perekonomian terbuka.

Isu berikutnyaadal ah mencoba untuk melihat al ternatif yang ketiga yaitu penggunaan combination policy antara suku bunga dengan money stock. Optimal policy diperlihatkan dalam persamaan berikut ini:

dimana:

$$
\mathrm{C}_{0} \mathrm{M}=\mathrm{C}_{1} *+\mathrm{C}_{2}{ }^{*} \mathrm{r} \text {, }
$$

$\mathrm{C}_{0} \quad=$ denominator Money Stock Policy

$\mathrm{C}_{1} \quad=$ denominator Combination Policy

$\mathrm{C}_{2} \quad=$ denominator Interest RatePolicy.

Dari persamaan tersebut, terlihat bahwa combination policy cenderung bergerak menjadi puremoney stock policy jika $C_{2}=0$, cenderung kearah pureinterest ratejika $C_{0}=0$, sementarajika 
$\mathrm{C}_{2}$ dan $\mathrm{C}_{0}$ keduanya mendekati 0 maka combination policy menjadi superior dibanding kedua jenis purepolicy. Hasil perhitungan $\mathrm{C}_{0}$ dan $\mathrm{C}_{2}$ secara berturut-turut adalah 0.0046 dan 0.1338 - kedua denominator tersebut mendekati 0 - yang berarti combination policy $\left(C_{1}\right)$ relatif lebih dominan. Hal ini didukung oleh hasil perhitungan minimum expected loss combination policy sebesar 0.0013 - relatif lebih rendah dibandingkan dengan kebijakan pureinterest rate maupun puremoney stock yang juga menyiratkan superioritas dari combination policy atas dua pendekatan yang lain. M eskipun demikian, seperti yang dikemukakan oleh Poole, penerapan combination policy dalam praktek pengendalian moneter relatif sulit, dimana keberhasilan penerapannya akan sangat tergantung pada seberapajauh pemahaman policy maker tentang hubungan antara suku bunga dan money stock karena sensitifitas dari denominator suku bunga terhadap money stock dan sebaliknya.

Hasil analisa Pooleyang merekomendasikan instrumen suku bunga sejalan dengan hasil pengujian mekanisme transmisi dengan menggunakan analisis time series. Namun demikian suatu catatan kritis dari hasil analisa Pooledi atas perlu dikemukakan. Salah satu kelemahan metodePoole, seperti yang sudah dikemukakan dalam Bab 2, adalah sensitifitas analisis tersebut yang sangat bergantung pada parameter-parameter yang dihasilkan oleh persamaan struktural IS-LM. Dengan demikian, perubahan pada besarnya parameter yang dihasilkan oleh persamaan tersebut - baik yang disebabkan oleh perubahan jumlah sampel maupun besaran moneter yang digunakan - akan sangat mempengaruhi konklusi dari metodeini.

Uji Stabilitas dari persamaan IS-LM dengan menggunakan chow test, yaitu dengan membagi periode observasi menjadi dua (1989:3 sd. 1995:1, dan 1995:1 sd. 1999:1) menunjukkan bahwa persamaan LM di atas tidak stabil. Artinya, parameter yang dihasilkan juga bersifat tidak stabil, sehingga konklusi Analisis Poole yang dihasilkan kemungkinan dapat berubah.

\section{Penggunaan Suku Bunga Sebagai Target O perasional Kebijakan M oneter}

Dengan latar belakang teoritis pada Bab2, dan pengujian empiris untuk kasus Indonesia pada Bab 3, pembahasan tentang penggunaan suku bunga sebagai target operasional kebijakan moneter pada bab ini akan menyajikan diskusi tentang implementasi kebijakan yang relevan untuk konteks perekonomian Indonesia. Bagian pertama membahas tinjauan historis kebijakan moneter di Indonesia dan kemungkinan penggunaan instrumen suku bunga. Penggunaan instrumen suku bunga di negara-negara lain pada bagian selanjutnya dimaksudkan sebagai studi komparatif untuk mengetahui hal-hal yang perlu dipahami dalam mengimplementasikan kebijakan moneter. Selanjutnya, perumusan kerangka kebijakan moneter dari mulai instrumen moneter sampai kepada pencapaian 
sasaran inflasi dimaksudkan untuk merepresentasikan bekerjanya mekanisme transmisi kebijakan moneter dengan instrumen suku bunga. Terakhir, diskusi tentang pendekatan rules versus discretion berusaha untuk memberikan latar belakang perlunya suatu policy rules sebagai benchmark bagi kebijakan moneter, disamping tinjauan kritis tentang masih diperlukannya ruang bagi kebijakan moneter yang bersifat discretion. Dalam hal ini, peran dari policy rules yang menerjemahkan respon kebijakan moneter melalui suku bunga masi membutuhkan assesment dari pergerakan berbagai information variables yang "berada di luar sistem".

\section{Kebijakan Moneter di Indonesia: Tinjauan Historis}

Jalur suku bunga dalam mekanismetransmisi kebijakan moneter di Indonesia, seperti sudah dibahas dalam babsebelumnya, merupakan channel yang penting untuk kasus Indonesia. Beberapa hasil penelitian terdahulu di Bank Indonesia mengkonfirmasi temuan ini, dan menyarankan penggunaan paradigma baru bagi kerangka kebijakan moneter berdasarkan jalur suku bunga (lihat Sarwono dan Warjiyo, 1998, atau Warjiyo dan Zulverdi, 1998).

Namun, merubah kerangka kebijakan moneter bukan suatu hal yang mudah dilakukan, terutama karena pemahaman atas jalur-jalur mekanisme transmisi cukup sulit untuk diketahui secara pasti. Akibatnya, bahkan negara maju seperti A merika Serikat menggunakan kebijakan moneter yang bersifat pragmatis (eclictic). Artinya, respon kebijakan moneter tidak didasarkan pada variabel-variabel yang berasal dari satu jalur tertentu dari mekanisme transmisi, melainkan pada assesment perekonomian yang diperoleh dari informasi berragam indikator ekonomi yang relevan.

Dalam kerangka yang sudah lama berlaku di Indonesia, mekanisme transmisi kebijakan moneter diawali dari monetary base sebagai target operasional. M elalui monetary aggregatesebagai intermediatetarget, kebijakan moneter dianggap mampu mempengaruhi output dan inflasi. Meski pendekatan kuantitas dapat dianggap efektif selama kurun waktu yang lalu, khususnya sejak awal tahun 1990-an pendekatan tersebut mendapat tantangan yang cukup berat. Perkembangan yang sangat cepat di pasar uang akibat serangkaian deregulasi dan semakin terintegrasinya perekonomian domestik dengan luar negeri menyebabkan hubungan antara agregat moneter dengan output dan inflasi menjadi tidak stabil. ${ }^{17}$ A kibatnya, kebijakan moneter berdasarkan pendekatan kuantitas menjadi kurang dapat diandalkan.

17 Fenomena seperti ini sudah sejak lama dijumpai di negara maju, dan merupakan alasan utama bagi ditinggalkannya pendekatan quantity based structure dalam kerangka kebijakan moneter tetap terjaga dalam kisaran yang diinginkan. Meski operasi moneter tersebut hanya dilakukan pada suku bunga overnight, hal ini sudah cukup bagi RBNZ untuk mempengaruhi ekspektasi pelaku pasar dalam penentuan suku bunga yang lebih panjang. Dengan kata lain, RBNZ secara efektif berperan dalam pembentukan struktur yield curve yang diinginkan. 
Menghadapi tantangan tersebut, Bank Indonesia kemudian mengadopsi kerangka kebijakan yang bersifat pragmastis (eclectic approach). Tanpa meninggalkan pendekatan kuantitas, perhatian atas perkembangan suku bunga semakin ditingkatkan, sementara kisaran intervensi dalam kerangka managed exchange rate regime semakin diperlebar untuk mengurangi beban kebijakan moneter.

Pendekatan pragmatis tersebut diperkirakan akan digunakan untuk sementara waktu, sebel um akhirnya beralih kepada pendekatan baru berdasarkan interest ratetargeting. Namun, sebelum rencana tersebut dapat dilaksanakan, resesi ekonomi - yang antara lain ditandai dengan penyaluran bantuan likuiditas dalam jumlah yang sangat besar, memaksa kebijakan moneter untuk tetap menggunakan pendekatan agregat moneter. Dalam hal ini, kebocoran moneter yang berasal dari bantuan likuiditas harus diserap kembali, sehingga sumber-sumber penciptaan uang beredar yang menyebabkan inflasi dapat dikendalikan.

Dalam praktek kebijakan moneter selama masa krisis, bahkan sebelum berlakunya Undang-Undang Bank Indonesia yang baru, kebijakan moneter sudah difokuskan kepada pencapaian kestabilan nilai rupiah dengan mengandalkan kepada monetary transmission channel. Secara formal beberapa kutipan berikut ini mengkonfirmasi kerangka kebijakan moneter dengan sasaran tersebut. "U paya untuk mencapai kestabilan harga dan nilai tukar pada dasarnya dilakukan dengan mempertajam sasaran kuantitatif kebijakan moneter, meningkatkan efektivitas OPT, mengendalikan ekspansi BLBI, dan memulihkan akses ke sumber pembiayaan LN" (laporan tahunan BI 98/99). Demikian hal nya, "U payastabilisasi baik harga maupun nilai tukar rupiah hanya dapat dicapai melalui pengendalian jumlah uang beredar secaraterukur... Di dalam kondisi krisis, prioritas pertama adalah bagaimana mengendalikan jumlah uang beredar (base money), sedangkan suku bunga lebih banyak ditentukan oleh kekuatan mekanisme pasar." (Pengarahan Direksi Bidang M oneter dalam Rapat Kerja Bank Indonesia, Jakarta, 25 November 1998). Dalam hal ini, pengendalian base money melalui open market operation (OMO) dilakukan melalui dua instrumen utama, yaitu penjualan SBI dan intervensi langsung di pasar uang antar bank (intervensi rupiah). Sementara itu, guna mengendalikan ekspansi moneter yang berasal dari pengeluaran pemerintah dan sekaligus menambah pasokan valas untuk stabilisasi rupiah, BI melakukan sterilisasi di pasar uang valas.

Namun, seperti sudah disinggung sebelumnya, penggunaan quantity-based structure sebagai kerangka kebijakan moneter pada masa krisis lebih dilakukan karena pertimbangan besarnya kebocoran moneter yang harus diserap, bukan oleh pertimbangan yang lebih mendasar seperti adanya hubungan yang stabil antara inflasi dan agregat moneter. Beberapa penelitian bahkan menunjukan kurang validnya asumsi yang mendasari pendekatan agregat moneter, misalnya bahwa money multiplier dan velocity of money tidak cukup stabil untuk kasus Indonesia (Solikin, 1998). 
Kebijakan moneter berdasarkan quantity-based structure sel ama masa krisis memang diakui efektif, terutama karena hal itu dapat secara langsung mengatasi sumber permasalahan kebocoran moneter. Namun, kedepan, dengan asumsi bahwa kebocoran moneter tersebut sudah dapat diatasi, pemikiran untuk menggunakan kerangka kebijakan moneter yang baru, perlu terus dilakukan khususnya dengan mempertimbangakan efektivitaskebijakan moneter dalam mencapai sasaran inflasi.

\section{Penggunaan Suku Bunga Jangka Pendek Sebagai Target Operasional: Studi Komparatif di Berbagai Negara}

Debatpada level teoritismaupun implementasi kebijakan tentang mekanismetransmisi memang masi tetap menjadi kontroversi. Sementara itu, kebutuhan bagi bank sentral untuk mengetahui jalur mekanisme mana yang paling efektif mempengaruhi sasaran akhir tidak dapat ditunda hingga debat tersebut menjadi konklusif. Penerapan kerangka kebijakan inflation targeting sendiri tidak secara eksplisit mengatakan tentang bagaimana bank sentral dapat mencapai sasaran inflasinya. $\mathrm{N}$ amun pada umumnya negara-negara yang menerapkan inflation targeting sekarang ini menggunakan suku bunga sebagai sasaran operasional kebijakan moneter. Demikian hal nya, negara-negara yang tidak secara eksplisit menerapkan inflation targeting juga semakin banyak menggunakan instrumen suku bunga, terutama dengan pertimbangan tidak stabilnya hubungan antar agregat moneter maupun antara agregat moneter dan sasaran akhir.

Pengalaman Reserve Bank of New Zealand (RBNZ) yang beralih dari jalur quantity (settlement cash) kesuku bunga (OCR, official cash rate) menunjukan proses "evolusi" yang berharga untuk dipelajari. Sejak diberlakukannya inflation targeting sebagai kerangka kerja kebijakan moneter, paling tidak sudah terjadi 3 kali perubahan implementasi kebijakan yang cukup mendasar. Pada awal penerapan, target kuantitas melalui primary liquidity dan kemudian settlement cash (giro bank di reserve bank) diandalkan sebagai jalur utama mekanismetransmisi. Setelah diyakini bahwa jalur "price" lebih relevan bagi implementasi kebijakan, pada awal tahun $1997 \mathrm{MCl}$ (mon etary condition in dex) digunakan sebagai sasaran operasional kebijakan moneter. Selanjutnya, sejak Februari 1999, official cash rate (OCR) menggantikan peran $\mathrm{MCl}$, dengan pertimbangan bahwa penggunaan $\mathrm{MCl}$ tersebut justru menimbulkan fluktuasi suku bunga dan kurang sesuai dengan standar internasional (meminjam istilah mereka: international ly-unusual, and unnecessarily-complex operating system).

Ketidakpuasan atas penggunaan settlement cash sebagai target operasional khususnya tertuju pada kelemahannya dalam memberikan signal kebijakan moneter kepada pasar. Dalam hal ini, pasar sulit untuk menterjemahkan signal kebijakan moneter dari, misal nya, kenaikan sekian dolar settlement cash target. Untuk mengatasi kelemahan tersebut, implementasi 
kebijakan moneter biasanya juga ditunjang oleh statement-statement, baik yang bersifat resmi atau informal, untuk mempertegas signal kebijakan moneter. Pada prakteknya, tentu sulit untuk mengukur efektivitas dari suatu statement.

Selanjutnya, perpindahan dari jalur "quantity" ke "price" tidak dengan sendirinya menggunakan suku bungasebagaimana yang lazim digunakan secara internasional. Dengan pertimbangan bahwa kebijakan moneter sebagian besar ditransmisikan melal ui jalur suku bunga dan nilai tukar sebelum akhirnya mempengaruhi inflasi, maka ketersediaan suatu indikator moneter yang memperhitungkan keduavariabel tersebut menjadi sangat penting. $\mathrm{MCl}$ kemudian dibentuk dengan menggunakan bobot 2:1 untuk suku bunga berjangka 90 hari dan real exchange rates (TWI, tradeweighted index). Dengan menetapkan $\mathrm{MCl}$ yang sejalan dengan targetinflasi, maka kebijakan moneter mengarahkan suku bunga agar dapat mencapai target $\mathrm{MCI}$ tersebut. Pada prakteknya, meskipun pencapaian $\mathrm{MCI}$ meng-gunakan indicative band, shock yang terjadi pada nilai tukar menyebabkan fluktuasi yang berlebihan pada suku bunga karena harus mempertahankan nilai $\mathrm{MCl}$ ter-tentu. Fluktuasi tersebut terutama terjadi selama periodeintra-quarter, karena target $\mathrm{MCl}$ dibentuk secara kuartalan (data inflasi yang tersedia di New Zealand ada-lah triwulanan).

Dengan pertimbangan bahwa volatilitas suku bunga yang terjadi cukup merugikan, maka RBNZ agak mengendurkan pencapaian target $\mathrm{MCl}$. A kibatnya, sebagai target $\mathrm{MCl}$ mulai kehilangan fungsinya. Krisis nilai tukar di Asia yang berdampak juga terhadap nilai tukar New Zealand merupakan pemicu bagi dilepas-kannya fungsi $\mathrm{MCl}$ sebagai target operasional. Dengan menggunakan suku bunga sebagai target operasional sejak awal tahun 1999 dan memfungsikan MCI sebatas sebagai “indikator", diharapkan suku bunga dapat berfungsi dengan lebih jelas dan efektif dalam memberikan signal kebijakan moneter.

Pertimbangan lain yang lebih mendasar adalah bahwa pengaruh pass-through dari nilai tukar terhadap inflasi semakin berkurang, sehingga respon kebijakan moneter dalam menghadapi shock nilai tukar dapat lebih difokuskan kepada pengaruh shock yang bersifat tidak langsung. Dalam jargon kebijakan moneter, dapat dikatakan bahwa respon kebijakan moneter lebih bersifat "flexible" ketimbang bersifat "strict". Artinya, meski shock nilai tukar memberikan pass-through effect, kebijakan moneter tidak perlu meresponnya secara strict untuk berupaya kembali kedalam target inflasi sesegera mungkin. Di sini peran timehorizon dalam pencapaian target inflasi menjadi penting. Dalam situasi ini, penggunaan $\mathrm{MCl}$ sebagai target operasional bisa jadi missleading.

Dari segi day-to-day operation, penggunaan suku bunga berjangka pendek sebagai sasaran operasional menjadikan operasi kebijakan moneter menjadi lebih sederhana, sehingga signal kebijakan moneter dapat ditangkap dengan lebih jelas. Review atas target 
OCR ${ }^{18}$ dilakukan setiap 6 minggu, sedangkan assesment terhadap perekonomian secara makro yang menghasilkan proyeksi inflasi tetap dilakukan setiap triwulan dan di-published dalam M onetary Policy Statements. Penyesuaian OCR, bila diperlukan, dilakukan dalam kelipatan 25 basis points.

Negara lain yang menerapkan inflation targeting, seperti Inggris dan Kanada, juga menggunakan suku bungajangka pendek sebagai target operasional. Di Inggris, pencapaian target official rate selain diyakini akan berpengaruh terhadap struktur suku bunga lain yang berjangka lebih panjang, juga akan mempengaruhi harga aset, ekspektasi, dan nilai tukar. Secara bersama-sama, ke empat hal tadi akan mempengaruhi permintaan agregat, dan memberikan tekanan inflasi apabila menghasilkan output gap yang positif. Di Kanada, pencapaian suku bungajangka pendek diarahkan untuk mencapai sasaran kondisi moneter yang didefinisikan sebagai monetary condition index $(\mathrm{MCl})$.

Di negara yang tidak secara eksplisit menerapkan inflation targeting, penggunaan suku bunga jangka pendek sebagai target operasional kebijakan moneter juga lazim dilakukkan. Federal ReserveSystem di AmerikaSerikatmenggunakanfederal funds ratesebagai target bagi kegiatan open market policy-nya. Bundesbank memfungsikan lombard rate dan rediscount rate masing-masing sebagai batas atas dan batas bawah bagi pergerakan suku bunga di pasar uang.

\section{Kerangka Kebijakan Moneter dengan Target O perasional Suku Bunga Jangka Pendek}

Dari sisi operasional kebijakan moneter, pertimbangan pragmatis dari digunakannya suku bunga sebagai instrumen utama kebijakan moneter adalah karena pasar uang lebih mudah menangkap signal kebijakan moneter melalui suku bunga, dibandingkan melalui agregat moneter. Temuan pada Bab 3 yang menunjukan bahwa perubahan suku bungaSBI secara segera (initial shock) direspon oleh pasar uang antar bank, secara implisistmenunjukan efektifnya instrumen suku bunga sebagai alat bagi Bank Indonesia untuk megkomunikasikan stance kebijakan moneternya. Bagi negara yang menerapkan inflation targeting, efektivitas signal kebijakan moneter ini menjadi sangat penting, karena di dal am kerangka kebijakan moneternya terdapat variabel ekspektasi yang juga berusaha untuk dipengaruhi melalui kebijakan moneter. Dengan kompleksitas mekanisme transmisi kebijakan moneter yang semakin tinggi dan penggunaan strategi pengendalian [agregat] moneter yang semakin berkurang efektivitasnya tentu saja akan menjadi sulit bagi bank sentral untuk dapat

18 Dalam pelaksanaannya, OCR berfungsi sebagai titik tengah dari suku bunga PUAB overnight. RBNZ akan memberikan suku bunga sebesar 25 basis point di bawah OCR bagi penempatan dana bank-bank di RBNZ (settlement cash). Sebaliknya, RBNZ akan memberikan dana overnight-nya dengan suku bunga sebesar 25 bp di atas OCR di pasar uang antar bank. Dengan demikian, suku bunga PUAB 
memberikan penjelasan yang tepat mengenai 'stance' kebijakan dan sasaran yang ingin dicapai kepada masyarakat (Alamsyah dan Masyhuri, 1999).

Selain dari signal kebijakan yang lebih mudah ditangkap, penggunaan suku bunga jangka pendek sebagai instrumen juga lebih sesuai dengan kriteria efektivitas instrumen yang lain yang sering disinggung dalam literatur moneter. Mishkin (1992) menginventarisasi tiga kiriteria dimaksud: 1) M easurability: suatu instrumen harus dapat diukur secara cepat dan akurat. Dalam hal ini data suku bunga dapat diperoleh relatif lebih cepat dibandingkan agregat moneter; 2) Controllability: Otoritas moneter harus dapat mengontrol instrumennya secara efektif. Kenyataan tingginya angka pertumbuhan agregat moneter, baik sebelum maupun semasa krisis, menunjukan lemahnya kontrol bank sentral atas instrumen ini. Sementeraitu, suku bunga bergerak lebih stabil; 3) A bility to predictably affect goals: instrumen moneter harus mempunyai pengaruh yang predictableterhadap sasaran moneter. Pembahasan dalam bab III membuktikan bahwa pengaruh instrumen suku bunga terhadap inflasi mempunyai hubungan yang lebih stabil dibandingkan dengan agregat moneter.

Meskipun sebagai instrumen suku bunga relatif lebih baik dibandingkan agregat moneter, tidak berarti bahwa jalur agregat moneter kehilangan fungsinya dalam mekanisme transmisi. Temuan pada Bab 3 mengkonfirmasi eksistensi baik jalur suku bunga maupun jalur agregat moneter. Diskusi teoritis maupun implementasi kebijakan tentang pengaruh kebijakan moneter telah sejak lama menjadi kontroversi. Secara umum, diskusi tersebut cenderung menyimpulkan bahwa proses transmisi kebijikan moneter sendiri bersifat sangat kompleks dan tidak pasti. Suatu kebijakan tidak akan mempengaruhi sasarannya hanya melalui satu jalur tertentu (Barran, et al., 1996). Mekanisme transmisi dapat berbeda pada masing-masing perekonomian, atau bahkan berbeda untuk setiap kurun waktu pada perekonomian yang sama.

A danya ketidakpastian dalam proses transmisi kebijakan moneter tersebut kemudian melahirkan suatu kerangka kebijakan moneter yang bersifat pragmatis, termasuk padanegaranegara yang menerapkan inflation targeting. Artinya, otoritas moneter tidak mendasarkan kebijakan moneternya hanya pada informasi yang diperoleh dari variabel-variabel dalam suatu jal ur transmisi tertentu, melainkan juga pada informasi dari variabel lain yang diangap relevan dengan target inflasi. Meskipun demikian, pada umumnya framework kebijakan moneter di negara-negara tersebut lebih mendasarkan kepada jalur suku bunga sebagai jalur utama. Disamping itu, informasi dari variabel-variabel lain yang relevan - termasuk agregat moneter - tetap mendapatkan perhatian, yaitu dalam fungsinya sebagai information variables. Sistem operasi kebijakan moneter pada Gambar 1 menggambarkan kerangka dimaksud. 


\section{G ambar 1.}

Perbandingan Sistem 0 perasi Kebijakan M oneter

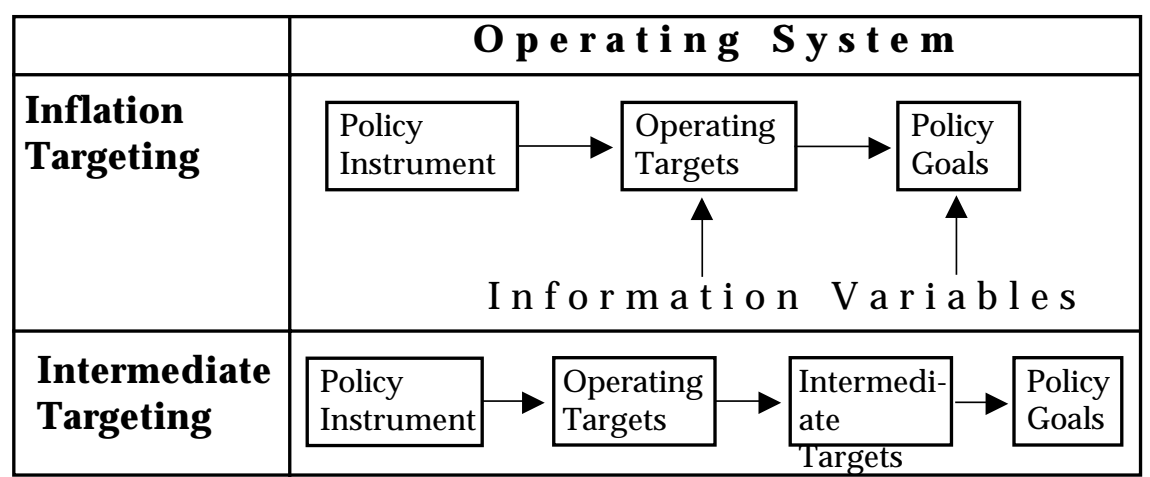

Sumber : Junggun $\mathrm{Oh}$. Inflation Targeting, M onetary Transmission M echanism and Policy Rules in Korea. Economic Papers V o. 2., N o. 1 M arch 1999, The Bank of Korea

Dalam kerangka inflation targeting, fungsi inter mediatetarget tidak disebutkan secara eksplisit. Namun demikian, beragam information variables digunakan dalam fungsinya sebagai leading indikator tekanan inflasi inflasi. Dal am hal ini, agregat moneter diletakkan di luar sistem, yaitu sebagai information variables. Base money dapat digunakan sebagai indikator target operasi onal suku bungajangka pendek, sedangkan jumlah uang beredar baik dalam arti sempit maupun luas (M1 dan M2), dan kredit sebagai indikator agregat moneter. Disamping itu, beberapa hasil survey ekspektasi dan leading indikator inflasi berfungsi sebagai information variables bagi tekanan inflasi.

Dengan mengutip hasil penelitian Svensson (1996), Alamsyah dan Masyhuri (1999) tidak menyarankan penggunaan intermediate target dalam pengertian yang konvensional. A pabila definisi sasaran antara adalah suatu variabel yang perkembangannya bisa diikuti setiap saat dan berfungsi sebagai petunjuk operasional kebijakan moneter untuk mencapai sasaran akhir, maka sasaran antara yang paling ideal untuk inflation targeting adalah prediksi inflasi (expected inflation) itu sendiri. Dengan melakukan prediksi inflasi secara berkala maka bank sentral akan mengetahui arah inflasi ke depan. A pabila menurut hasil prediksi, target inflasi akan terlampaui maka otoritas moneter secara dini segera akan melakukan pengetatan dan demikian juga sebaliknya.

Untuk suatu perekonomian yang terbuka, Svensson (1997) menginventarisir tigajalur transmisi yang paling penting: (1) jal ur permintaan agregat melalui perubahan suku bunga, (2) jalur ekspektasi, dan (3) jalur nilai tukar. Dengan juga mendasarkan pada temuan yang sudah dibahas di Bab 3, skema pada Gambar 2 menggambarkan alur mekanismetransmisi kebijkan moneter yang lebih lengkap, yang dapat diaplikasikan untuk kasus Indonesia. Skema tersebut merupakan modifikasi dari kerangkayang digunakan oleh Bank of England (The Monetary Policy Committee, Bank of England, 1999). Pada skema tersebut, 
operasionalisasi kebijakan moneter masih mengacu kepada apa yang ada sekarang, yaitu OMO, fasilitas diskonto, giro wajib minimum, dan intervensi valas. Ke depan, penelitian tersendiri tentang implementasi kebijakan moneter yang relevan dengan target operasional suku bunga perlu dilakukan, khususnyayang berkaitan dengan formulasi day-to-day monetary policy implementation.

Pada dasarnya, skema tersebut berawal dari operasi kebijakan moneter yang diarahkan untuk mempengaruhi suku bunga jangka pendek sebagai target operasional. Selanjutnya, perubahan suku bunga jangka pendek mempengaruhi berbagai variabel seperti suku bunga berjangka lebih panjang, harga aset (diwakili oleh indeks harga saham gabungan di Bursa Efek Jakarta), variabel ekspektasi, dan nilai tukar.

Keseluruhan variabel tersebut kemudian berpengaruh terhadap preferensi masyarakat, yang tercermin dari perubahan domestic demand, khususnya konsumsi dan investasi. Disamping itu, nilai tukar berpengaruh secara langsung terhadap net external demand (ekspor dikurangi impor). Pengel uaran pemerintah, sebagai bagian dari total demand, tidak dapat secara langsung dipengaruhi oleh kebijakan moneter, melainkan oleh kebijakan di sisi fiskal. Selanjutnya, total demand yang sebagian dapat dipengaruhi oleh kebijakan moneter tersebut baru akan menimbulkan tekanan inflasi domestik apabila menghasilkan output gap yang positif. Artinya, total demand lebih besar dari total supply (potential output). Disamping "jalur utama" mekanismetransmisi melalui output gap, nilai tukar mempunyai pengaruh terhadap inflasi yang bersifat lebih langsung (passthrough effect), yaitu melalui kenaikan harga barang impor.

G ambar 2.

M ekanismeTransmisi Kebijakan M oneter di Indonesia

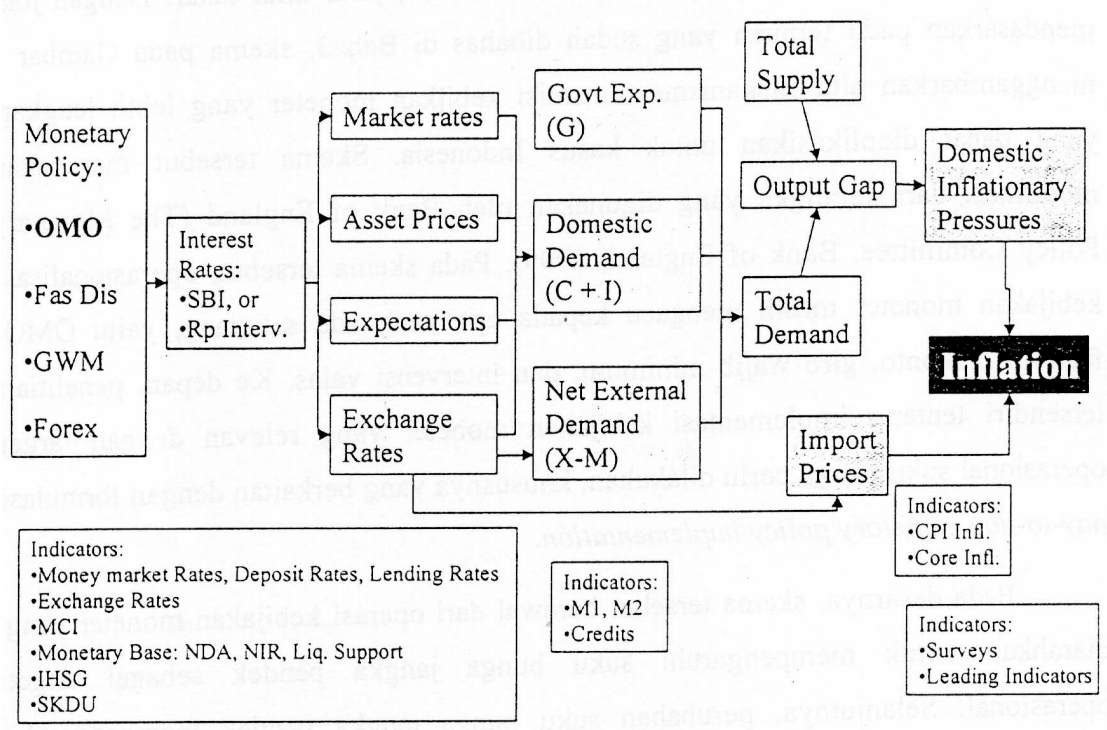


Filosofi penting dari mekanisme transmisi ini adalah bahwa kebijakan moneter terutama bekerja melalui pengaruhnya atas perminataan agregat, dan hampir tidak mempunyai pengaruh langsung atas kapasitas supply. Dalam jangka panjang, kebijakan moneter pada dasarnya menentukan nilai mata uang. Atau, dalam ungkapan yang lebih populer, inflasi adalah fenomena moneter. Dengan mendasarkan pada pandangan ini, sasaran tunggal inflasi adalah tujuan paling relevan bagi kebijakan moneter. Disamping itu, penekanan time horizon dari pandangan ini, yaitu bahwa pengaruh kebijakan moneter lebih dilihat dalam jangka panjang, menyebabkan pentingnya peran output gap sebagai indikator tekanan inflasi domestik.

Sebagaimana telah diuraikan dalam Bab III, monetary policy lag dari mulai perubahan instrumen (SBI) sampai kepada inflasi membutuhkan waktu sekitar dua tahun. Perubahan suku bunga SBI direspon sangat cepat oleh suku bungayang lebih panjang (0sampai dengan 1 kuartal), sedangkan perubahan suku bunga deposito perbankan membutuhkan waktu sekitar satu tahun untuk sampai kepada output gap. Selanjutnya, perubahan output gap membutuhkan waktu 3 kuartal sampai benar-benar mempengaruhi inflasi.

Sementara itu jalur w ealth effect melalui asset price (diwakili oleh IHSG) tidak terlalu kuat. Respon IHSG terhadap perubahan SBI rate tidak cukup kuat, sedangkan terhadap perubahan suku bunga deposito membutuhkan lag sekitar 2 kuartal. Perubahan IHSG selanjutnya membutuhkan lag sekitar 3 kuartal untuk dapat mempengaruhi output gap.

Dari jalur nilai tukar, perubahan nilai tukar riil (real effective exchange rate) mempengaruhi inflasi dengan segera, yaitu 0 sampai dengan 4 kuartal (passthrough effect). Disamping itu, perubahan nilai tukar riil juga direspon oleh output gap dengan lag sekitar 6 bulan. Namun, meskipun nilai tukar sangat kuat mempengaruhi imflasi, respon nilai tukar riil atas perubahan instrumen (SBI rate) membutuhkan waktu yang cukup lama, yaitu sekitar 6 bulan.

Dalam hal instrumen moneter, secarakonvensional bagi Bank Indonesiatelah tersedia suku bungaSBI dan intervensi rupiah ${ }^{19}$. Ke depan, penggunaan obligasi pemerintah sangat potensial sebagai instrumen moneter, seperti yang lazim dilakukan di negara lain. Dalam hal ini, operasi pasar terbuka (OPT) dapat dilakukan dengan penjualan maupun pembelian obligasi tersebut di pasar sekunder. Demikian halnya, penggunaan official cash rate (OCR) seperti yang telah dibahas terdahulu juga potensial sebagai alternatif instrumen, terlebih bila stabilitas suku bunga pasar uang antar bank dianggap sebagai hal yang penting. Dalam hal ini, instrumen yang telah ada sekarang, yaitu intervensi rupiah, dapat dikembangkan fungsinya menjadi OCR.

19 Dalam pengujian transmisi kebijakan moneter yang dianggap sebagai instrumen adalah SBI, berhubung tidak mencukupinya data intervensi rupiah. 
Suatu bank sentral berkemampuan mencapai target suku bunga tertentu karena kemampuannya menentukan high power money atau base money. Namun dalam rangka mencapai target operasional suku bunga, khususnya melalui kegiatan open market operation (O M O), terdapat beberapa detail yang agak berbeda di antara bank sentral. Dari segi implementasi kebijakan moneter untuk mencapai target suku bungajangka pendek paling tidak terdapat dua cara yang berbeda. Cara yang lazim dilakukan adalah mencapai target suku bungajangka pendek melalui aktivitas OMO yang aktif, dimana bank sentral melakukan aktivitas jual beli surat berharga di pasar sekunder hingga mencapai target suku bunga yang diinginkannya. Cara yang lain misalnyadipraktekan oleh ReserveBank of $\mathrm{N}$ ew Zeal and (RBNZ) dengan menentukan pergerakan suku bunga pasar uang antar bank secaralangsung melalui OCR. Dalam hal ini, OPT hanya dilakukan oleh RBNZ secara pasif.

Penelitian tersendiri yang mendalam tentang implementasi kebijakan moneter untuk kasus Indonesia perlu dilakukan dengan melihat beberapa kemungkinan penggunaan prosedur OPT yang berbeda dari lelang SBI sebagaimana yang selama ini dilakukan. Dalam hal ini, pengembangan pasar sekunder untuk obligasi pemerintah maupun pengembangan instrumen intervensi rupiah menjadi mekanisme semacam OCR sangat potensial untuk dilakukan.

Dengan pertimbangan sebagai suatu negara kecil yang terbuka, beberapanegara secara eksplisitmemasukan peran monetary condition index $(\mathrm{MCl})^{20}$, yang diperoleh dari gabungan suku bunga dan nilai tukar, ke dalam kedalam proses transmisi kebijakan moneter. Untuk kasus Indonesia, dimana variabel nilai tukar menjadi sangat diperhatikan terutama sejak terjadinya krisis ekonomi, peran $\mathrm{MCl}$ sebagai indikator kondisi moneter tidak diragukan menjadi sangat penting. Namun, sebagaimana yang terjadi di New Zeal and di mana suku bunga menjadi berfluktuasi untuk mempertahankan target $\mathrm{MCl}$, peran $\mathrm{MCl}$ dalam transmisi kebijakan moneter di atas dibatasi sebagai information variables, bukan sebagai target.

\section{Monetary Policy Rules and Discretion: Bagaimana Menentukan Suku Bunga untuk Mencapai Target Inflasi?}

Setelah memperoleh suku bungajangka pendek sebagai target operasional kebijakan moneter, pertanyaan penting selanjutnya adalah apakah Bank Indonesia harus secara aktif mempengaruhi suku bunga untuk mencapai target inflasinya melalui discretionary monetary policy approach, atau dapat secara pasif menyerahkannya kepada suatu policy rule? Atau, seperti kompromi yang sering disarankan, memfungsikan policy rules sebagai suatu

20 Kanada menggunakan MCI sebagai target operasional kebijakan moneter, di mana perubahan suku bunga diarahkan untuk mencapai target MCI tertentu. Sementara itu, New Zealand sejak awal tahun 1999 men-down grade peran MCI sebatas sebagai information variables, dengan pertimbangan untuk mengurangi volatilitas suku bunga. 
benchmark bagi kebijakan moneter, dengan tetap memberikan ruang bagi kebijakan yang bersifat discretion?

Debat di kalangan ekonom tentang apakah bank sentral harus menggantikan pendekatan kebijakan moneter yang bersifat discretionary dengan suatu rule yang bersifat mekanis telah sejak lama menjadi kontroversi. Meskipun pada umumnya kalangan bank sentral lebih memilih pendekatan discretionary policy, namun diskusi terkini tentang kerangka kebijakan inflation targeting telah menghi dupkan kembali argumen tentang perlunya suatu policy rule bagi bank sentral. Dalam hal ini, policy ruleyang banyak dibahas mengacu kepada Taylor rule(Taylor, 1993) yang secara eksplisit mengkaitkan respon kebijakan moneter dengan target inflasi.

Debat lamatentang perlunya policy rulemengacu kepadak\% ruledari Milton Friedman yang menekankan perlunya suatu bank sentral menerapkan kebijakan moneter yang bersifat mekanis (automatic servo-mechanism), yaitu menjaga pertumbuhan uang beredar pada suatu tingkat tertentu yang sudah ditetapkan ( $\mathrm{k} \%$ growth). Bentuk policy rule yang lain adalah dengan mematok nilai tukar (pegging exchange rate), atau juga mematok suku bunga riil jangka pendek pada suatu rate tertentu. Ketiga bentuk rules tersebut dapat dikelompokan menjadi satu, karena pada dasarnya masing-masing mematok nilai tertentu padainstrumen kebijakan (Blinder, 1998).

Kelompok yang lain, yang terutama muncul belakangan ini, mendasarkan policy rulesnya pada sasaran kebijakan moneter, bukan pada instrumennya. Mentargetkan tingkat inflasi atau pertumbuhan PDB nominal pada level tertentu masuk dalam kategori ini. Namun, Blinder (1998) meragukan pendekatan ini sebagai suatu policy rules. Menurutnya, target inflasi atau PDB adalah suatu objective, dan bagaimana cara mencapainya bisa jadi membutuhkan pendekatan yang bersifat discretionary policy. Dengan demikian, pendekatan tersebut tidak dapat dikategorikan sebagai policy rules.

Dalam beberapa waktu terakhir, policy rules yang mengacu pada Taylor type rules banyak menjadi rujukan, khususnya dalam kerangka kebijakan moneter dengan sasaran inflasi. Taylor rules pada dasarnya adalah suatu reaction function bagi bank sentral, yang merekomendasikan tingkatsuku bungatertentu dari instrumen kebijakan moneter (misal nya federal funds rate di Amreika Serikat) berdasarkan suatu keadaan perekonomian yang dihadapi. Misal nya, Taylor rule akan merekomendasikan kenaikan tingkat bunga apabila angka inflasi melebihi targetnya, atau merekomendasikan penurunan apabila terjadi ancaman resesi (Kozicki, 1999). Taylor rulemenjadi populer belakangan ini terutamakarena semakin lemahnya hubungan antara pertumbuhan uang beredar dan inflasi, sehingga policy rules yang mendasarkan pada pertumbuhan uang beredar menjadi sulit untuk diterima (Blinder, 1999). 
Secara lebih luas, policy rules dapat diartikan sebagai suatu sistem bagi bank sentral dalam menentukan respon kebijakan moneter. Di Indonesia, berdasarkan pendekatan quantitiy based structure, penggunaan policy rules mengacu kepada apa yang disebut sebagai program moneter. Program tersebut pada dasarnya didasarkan kepada fungsi permintaan uang yang diantaranya dipengaruhi oleh output dan inflasi. Dengan memproyeksikan atau bahkan mentargetkan variabel-veraibel yang mempengaruhi permintaan uang, khususnya output dan inflasi, maka didapatkan jumlah uang beredar yang sesuai untuk suatu periode tertentu. Jumlah uang beredar tersebut yang kemudian menjadi target bagi operasional kebijakan moneter.

Selama masa krisis, kebijakan moneter dalam paket kebijakan IMF bahkan mengikuti rule yang lebih ketat, yang pada dasarnya mengacu kepada k-percent money growth rule (McN elis, 1999). Kedepan, khususnya dengan mekanismetransmisi kebijakan moneter yang lebih mengandalkan jalur suku bunga (price), penelitian tersendiri mengenai formulasi policy rule yang sesuai untuk kasus Indonesia menjadi sangat penting.

Taylor rule yang secara eksplisit menterjemahkan respon kebijkan moneter dalam bentuk tingkat suku bunga tentu dapat dipakai sebagai acuan untuk memformulasikan policy rule untuk kasus Indonesia. Namun pembahasan dari banyak pihak - baik akademisi maupun praktisi bank sentral - tentang Taylor rulebanyak mengajukan kritik atau alternatif perbaikan untuk memperoleh policy rule yang lebih tepat (bahasan teoritis dapat dilihat pada Bab 2). Untuk membedakan dengan rumusan awal dari Taylor rule, berbagai alternatif perbaikan tersebut dapat disebut sebagai Taylor typerules.

Untuk memperoleh gambaran tentang formulasi policy ruleyang dapat digunakan di Indonesia, diskusi berikut ini menggambarkan beberapa pertimbanagn yang perlu diprehatikan dalam formulasi policy rulesyang dapat digunakan. Namun, karena formulasi policy rules membutuhkan penelitian tersendiri, diskusi ini hanya bermaksud untuk memberikan latar belakang bagi formulasi policy rulestersebut.

Bentuk awal dari Taylor ruleadalah sebagai berikut:

\section{Funds rate $(t)=$ GDP price inflation $(t)+2.0+0.5 X\{G$ D P price inflation $(t)-2.0\}+0.5 X$ outputgap (t)}

Dalam rumusan tersebut, acuan untuk rekomendasi funds rate diperoleh dari penjumlahan angka inflasi (GDP price inflation) dengan suku bunga riil equilibrium yang ditentukan sebesar $2 \%$. Elemen berikutnya adalah penyesuaian inflasi (inflation gap adjustment), yang merekomendasikan kenaikan funds ratesebesar 0.5 apabilaterjadi selisi antara angka inflasi dengan target inflasi (Taylor menentukan $2 \%$ sebagai target inflasi). Elemen terakhir adalah output gap adjustment, yang juga merekomendasikan kenaikan sebesar 
0.5 dari funds rate apabila terdapat output gap.

Secara kritis, Kozicki (1999) mengevaluasi penggunaan Taylor rule bagi kebijakan moneter di A merika Serikat. Setelah melakukan beberapa modifikasi dalam spefikasi Taylor rule, yaitu dengan membandingkan penggunaan beberapa alternatif inflasi yang digunakan (GDP deflator, headline CPI dan core CPI), output gap, suku bunga riil equilibrium, dan beberapa alternatif weight, ia menyimpulkan bahwaTaylor ruletidak cukup robust. A rtinya, dengan mengubah sebagian dari spesifikasi rule tersebut, rekomendasi suku bunga yang dihasilkan menjadi berbeda secara signifikan.

Evaluasi lain tentang Taylor rulemenyarankan perbaikan dalam beberapa hal, seperti perlunya interest ratesmoothing, yaitu dengan memasukan nilai lag dari suku bungakedalam policy rule. Penyempurnaan lain berkaitan dengan target inflasi yang digunakan. Beberapa paper menyoroti pentingnya policy rules yang bersifat forward looking (Batini and Haldane, 1998). Dalam hal ini, deviasi inflasi terhadap targetnya akan lebih baik jika menggunakan hasil proyeksi inflasi, sehingga rekomendasi perubahan suku bunga untuk saat ini ditujukan untuk mencapai target inflasi pada masa yang akan datang. Dalam jargon kebijakan moneter, pemikiran seperti ini yang kemudian melahirkan terminologi preemptivemonetary policy.

Dalam hal policy rules yang relevan untuk suatu perekonomian kecil yang terbuka (small open economy), beberapa paper menyarankan pentingnya memasukan komponen nilai tukar secara eksplisit ke dalam policy rules (Ball, 1998). Pemikiran ini yang kemudian memunculkan penggunaan monetary condition index $(\mathrm{MCl})$ dalam formulasi policy rule. Alternatifnya, time horizon dari policy rule perlu diperpanjang, untuk memberikan kesempatan bagi berkurangnya pengaruh nilai tukar yang bersifat temporer.

Untuk kasus Indonesia, pembahasan tentang formulasi policy rules yang relevan belum banyak dilakukan. Kesimpulan hasil penelitian McNelis (1999) bahwa respon kebijakan moneter melalui suku bunga di Indonesia sangat dipengaruhi oleh lag suku bunga, inflasi dan output gap, menunjukan bahwa formulasi Taylor type rules untuk kasus Indonesia sangat mungkin dilakukan ${ }^{21}$. McN elis justru menyarankan penggunaan bobot yang lebih besar untuk output gap dibanding untuk inflasi, mengingat masih banyaknya slack dalam perekonomian. Disamping itu, simulasi yang dilakukan menunjukan hasil yang lebih baik justru tanpa interest ratesmoothing.

Sebagai suatu perekonomian kecil yang terbuka (small-open economy), memasukan variabel nilai tukar secara eksplisit ke dalam policy rules juga patut menjadi pertimbangan.

21 Hasil pengujian empiris McNelis, dengan menggunakan data bulanan dari tahun 1989, cukup mengejutkan. Selama periode tersebut, respon kebijakan moneter di Indonesia sangat mirip dengan apa yang ada di Amerika Serikat pada masa Volker dan Greenspan, dimana kebijakan moneter melalui suku bunga sangat responsif terhadap pencapaian stabilitas harga. 
Pembahasan dalam Bab 2 menunjukan pentingnya variabel nilai tukar dalam formulasi policy rules untuk kasus small-open economy. Di samping itu, paper terakhir dari Taylor (1999) tentang monetary transmission dan evaluasi policy rules mengakui bahwa policy rules yang disusunnya lebih ditujukan bagi perekonomian besar seperti A merika Serikat. Untuk suatu perekonomian kecil yang terbuka, Taylor mengapresiasi hasil penelitian oleh Ball (1999) dan Svensson (1999) tentang perlunya memasukan variabel nilai tukar kedalam formulasi policy rules.

Sebagaimana telah dikemukakan sebelumnya, diskusi tentang pentingnya policy rules tidak dimaksudkan untuk digunakan secara strict. Peran agregat moneter yang berada di luar framew ork kebijakan moneter berdasarkan suku bunga, yaitu dalam fungsinya sebagai information variables, secara implisit menunjukan masih tersedianya ruang bagi kebijakan moneter yang bersifat discretion. Dalam hal ini, apabila terjadi shocks pada agregat moneter, formulasi yang tepat atas respon kebijkan moneter perlu juga diperhatikan.

Penggunaan policy rulesyang bersifat mekanistis, memang tidak dimaksudkan sebagai harga mati yang harus diikuti secara ketat oleh suatu bank sentral. Besarnya kondisi ketidakpastian seperti telah dibahas sebel umnya menyiratkan masi herlunya pendekatan yang bersifat discretion. Bernanke(1999) dalam kesimpulannya tentang framework kebijakan moneter di negara-negara yang menerapkan inflation targeting cenderung mengatakan bahwa kebijakan yang dipakai lebih bersifat discretion yang direstriksi oleh target inflasi. Blinder (1999) mengatakan bahwa debat tentang rules vs. discretion lebih banyak dilakukan di kal angan akademisi, sedangkan praktisi bank sentral lebih memilih pendekatan yang bersifat discretion. Demikian halnya, Svenson (1999) sangat berkeberatan dengan pendekatan rules yang kaku, dengan mengatakan bahwa apabila kebijakan moneter dapat diserahkan kepada sebuah policy rules, maka peran bank sentral dapat didelegasikan kepada seorang staf, atau bahkan kepada sebuah komputer.

Untuk kasus Indonesia, penggunaan sasaran tunggal inflasi memerlukan penerapan kebijakan moneter yang kredibel. Alamsyah dan Masyhuri (1999) menyarankan kompromi kebijakan yang bersifat di antara rules dan discretion. Dalam hal ini, praktek kebijakan moneter yang terlalu bersifat kompromistis akan condong untuk tidak memiliki suatu formulasi yang tegas dan menjadi kurang transparen. Bila pelaksanaan suatu kebijakan moneter terlampau diwarnai oleh kebijaksanaan (discretion) makaia akan kurang memiliki kredibilitas bila dibandingkan dengan pelaksanaan kebijakan moneter yang disandarkan kepada suatu aturan permainan yang tegas (rule). Dengan demikian, formulasi policy rules untuk kasus Indonesia sangat penting dalam fungsinya sebagai benchmark bagi kebijakan moneter. Sedangkan kebijakan yang bersifat discretionary policy berperan sebagai pelengkap bagi policy rules tersebut, khususnya dal am bentuk professional judgement bank sentral dalam melakukan 
assesment atas variabel-variabel ekonomi yang tidak secara langsung terkait dengan policy rules.

\section{Kesimpulan dan Saran Kebijakan}

Diskusi teoritis ataupun pengujian empiris tentang mekanisme transmisi kebijakan moneter belum menghasilkan kesimpulan yang bersifat final tentang jal ur transmisi mana yang sebaiknya digunakan oleh bank sentral sebagai dasar formulasi kebijakan moneter. Meskipun demikian, tampaknya jalur suku bunga (passive money approach) relatif bisa bisa menjelaskan dengan lebih baik proses transmisi tersebut dibandingkan dengan jalur agregat moneter (active money approach). Pembuktian empirisuntuk kasus Indonesia- melalui time series econometric maupun Poole's analysis- menunjukan kecenderungan tersebut, sedangkan kenyataan penggunaan-nya oleh negara-negara lain mengkonfirmasi temuan yang sama untuk kasusnegara-negara tersebut. $\mathrm{N}$ amun demikian, fakta tentang masi $\mathrm{h}$ bekerjanya jalur transmisi lewat agregat moneter menyarankan untuk tidak mengabaikan bekerjanya jalur transmisi melalui agregat moneter.

Penggunaan jalur suku bunga dengan demikian sebaiknya tidak murni menjadi substitusi bagi penggunaan jalur agregat moneter, misal nya dengan menghilangkan sama sekali peranan variabel agregat moneter di dalam formulasi kebijakan. Konsekuensi dari formulasi kebijakan moneter berdasarkan mekanismetransmisi melalui jalur suku bunga, memang menjadikan variabel agregat moneter menjadi berada "di luar sistem". Namun, dalam fungsinya sebagai salah satu information variables, pengamatan atas pergerakan variabel ini tetap penting untuk dilakukan.

Filosofi penting dari formulasi kebijakan moneter berdasarkan jalur suku bunga adalah bahwa kebijakan moneter bekerja melalui pengaruhnya atas perminataan agregat, dan hampir tidak mempunyai pengaruh langsung atas kapasitas supply. Dalamjangka panjang, kebijakan moneter pada dasarnya menentukan nilai mata uang. Dengan demikian, sasaran tunggal inflasi adalah tujuan paling relevan bagi kebijakan moneter. Disamping itu, penekanan pada pengaruh jangka panjang dari kebijakan moneter menyebabkan pentingnya peran output gap sebagai indikator tekanan inflasi domestik. Perubahan inflasi dalamjangka pendek akibat tekanan yang bersifat temporer, seperti misal nya pengaruh passthrough effect atau supply shocks, belum tentu harus direspon oleh kebijakan moneter.

Kerangka operasional kebijakan moneter diarahkan untuk mempengaruhi suku bunga jangka pendek sebagai target operasional. Selanjutnya, perubahan suku bungajangka pendek mempengaruhi berbagai variabel seperti suku bunga berjangka lebih panjang, harga aset, variabel ekspektasi, dan nilai tukar. Keseluruhan variabel tersebut kemudian berpengaruh terhadap preferensi masyarakat, yang tercermin dari perubahan domestic demand, khususnya 
konsumsi dan investasi. Disamping itu, nilai tukar berpengaruh secara langsung terhadap net external demand (ekspor dikurangi impor). Pengeluaran pemerintah, sebagai bagian dari total demand, tidak dapat secara langsung dipengaruhi oleh kebijakan moneter, melainkan oleh kebijakan di sisi fiskal. Selanjutnya, total demand yang sebagian dapat dipengaruhi oleh kebijakan moneter tersebut baru akan menimbulkan tekanan inflasi domestik apabila menghasilkan output gap yang positif. Artinya, total demand lebi h besar dari total supply (potential output). Disamping “jalur utama” mekanismetransmisi melalui output gap, nilai tukar mempunyai pengaruh terhadap inflasi yang bersifat lebih langsung (passthrough effect), yaitu melalui kenaikan harga barang impor.

Kesimpulan yang bersifat kompromistis dari diskusi tentang pendekatan rules versus discretion dalam perumusan kebijakan moneter menyarankan penggunaan policy rules sebagai benchmark bagi kebijakan moneter, dengan tetap memberikan ruang bagi kebijakan yang bersifat discretionary. Dalam hal ini penggunaan Taylor type rules yang menterjemahkan respon kebijakan moneter dalam bentuk suku bunga jangka pendek dapat dikembangkan untuk kasus Indonesia. Perumusan policy rules tersebut membutuhkan penelitian tersendiri dengan mempertimbangkan konteks perekonomian domestik, misalnya dengan menggunakan variabel yang relevan seperti tegret inflasi, output gap dan nilai tukar beserta dengan bobot (weight) yang optimal; atau memasukan unsur time horizon dengan mempetimbangkan karakteristik forward looking dari policy rules. 